\title{
How belowground interactions contribute to the coexistence of mycorrhizal and non-mycorrhizal species in severely phosphorus-impoverished hyperdiverse ecosystems
}

\author{
Hans Lambers (D) - Felipe Albornoz • Lukasz Kotula • \\ Etienne Laliberté • Kosala Ranathunge • \\ François P. Teste • Graham Zemunik
}

Received: 14 June 2017 / Accepted: 13 September 2017 / Published online: 30 September 2017

(C) Springer International Publishing AG 2017

\begin{abstract}
Background Mycorrhizal strategies are very effective in enhancing plant acquisition of poorly-mobile nutrients, particularly phosphorus $(\mathrm{P})$ from infertile soil. However, on very old and severely P-impoverished soils, a carboxylate-releasing and P-mobilising cluster-root strategy is more effective at acquiring this growthlimiting resource. Carboxylates are released during a period of only a few days from ephemeral cluster roots. Despite the cluster-root strategy being superior for $\mathrm{P}$ acquisition in such environments, these species coexist with a wide range of mycorrhizal species, raising questions about the mechanisms contributing to their coexistence.

Scope We surmise that the coexistence of mycorrhizal and non-mycorrhizal strategies is primarily accounted for by a combination of belowground mechanisms,
\end{abstract}

Responsible Editor: Philippe Hinsinger.

H. Lambers $(\bowtie) \cdot$ E. Laliberté $\cdot$ K. Ranathunge $\cdot$ F. P. Teste School of Biological Sciences, University of Western Australia, Crawley (Perth), WA 6009, Australia

e-mail: hans.lambers@uwa.edu.au

F. Albornoz

Department of Botany and Plant Pathology, Oregon State University, Corvallis, OR 973314, USA

L. Kotula

UWA School of Agriculture and Environment, University of

Western Australia, Crawley (Perth), WA 6009, Australia namely (i) facilitation of $\mathrm{P}$ acquisition by mycorrhizal plants from neighbouring cluster-rooted plants, and (ii) interactions between roots, pathogens and mycorrhizal fungi, which enhance the plants' defence against pathogens. Facilitation of nutrient acquisition by clusterrooted plants involves carboxylate exudation, making more $\mathrm{P}$ available for both themselves and their mycorrhizal neighbours. Belowground nutrient exchanges between carboxylate-exuding plants and mycorrhizal $\mathrm{N}_{2}$ fixing plants appear likely, but require further experimental testing to determine their nutritional and ecological relevance. Anatomical studies of roots of clusterrooted Proteaceae species show that they do not form a complete suberised exodermis.

Conclusions The absence of an exodermis may well be important to rapidly release carboxylates, but likely lowers root structural defences against pathogens,

\footnotetext{
E. Laliberté

Centre sur la biodiversité, Institut de recherche en biologie végétale, Département de sciences biologiques, Université de Montréal, 4101 Sherbrooke Est, Montréal, Québec H1X 2B1, Canada

F. P. Teste

Grupo de Estudios Ambientales, IMASL-CONICET \&

Universidad Nacional de San Luis, Av. Ejercito de los Andes 950, 5700 San Luis, Argentina

G. Zemunik

Smithsonian Tropical Research Institute, Apartado 0843-03092, Balboa, Ancon, Republic of Panama
} 
particularly oomycetes. Conversely, roots of mycorrhizal plants may not be as effective at acquiring $\mathrm{P}$ when $\mathrm{P}$ availability is very low, but they are better defended against pathogens, and this superior defence likely involves mycorrhizal fungi. Taken together, we are beginning to understand how an exceptionally large number of plant species and P-acquisition strategies coexist on the most severely P-impoverished soils.

Keywords Carboxylates, cluster roots · Competition . Facilitation · Hyperdiverse ecosystems · Mycorrhizas . Non-mycorrhizal plants $\cdot$ Phosphorus $\cdot$ Pathogen defence Proteaceae

\section{Introduction}

In the absence of major soil-rejuvenating processes (e.g., glaciations, volcanic eruptions), concentrations of soil phosphorus (P), one of the key plant macronutrients, decline over time, due to erosion and leaching (Walker and Syers 1976; Turner and Laliberté 2015), especially after fires (Lambers et al. 2014; Wittkuhn et al. 2017). By contrast, concentrations of nitrogen $(\mathrm{N})$ first increase during primary succession, and then decline over time (Walker and Syers 1976; Laliberté et al. 2012; Turner and Condron 2013). In seasonally-dry climates, loss of $\mathrm{N}$ through fires plays a major role (Wittkuhn et al. 2017). Compounding the decline of soil P stocks, much of what remains of the inorganic P is tightly bound (sorbed or occluded) to soil particles, with the remainder of the P being locked away in relatively inaccessible organic forms (Walker and Syers 1976; Turner and Condron 2013; Turner and Laliberté 2015). As a result, old soils tend to be severely P-impoverished, and, consequently, $\mathrm{P}$ is the major macronutrient limiting plant productivity (e.g., Richardson et al. 2004; Laliberté et al. 2012; Hayes et al. 2014).

A general trend, most pronounced in the northern hemisphere, is of increasing plant diversity approaching the tropics (i.e. with decreasing latitude) (Huston 1994). However, soil age tends to increase, and soil fertility decreases towards the equator, so changes in plant diversity may have little to do with latitude per se (Huston 2012). Studies from soil chronosequences, series of soils formed from the same parent material, but of contrasting soil ages, reduce many of the confounding factors that affect broad-scale latitudinal gradients (e.g., changes in climate) and have demonstrated consistent increases of plant diversity with soil age, suggesting that declining $\mathrm{P}$ availability is associated with increasing plant diversity (Wardle et al. 2008; Laliberté et al. 2013; Zemunik et al. 2016).

Several global biodiversity hotspots (Myers et al. 2000) contain P-impoverished soils, e.g., Southwest Australia, Cape Floristic Province in South Africa (McArthur 1991; Witkowski and Mitchell 1987; Cowling et al. 1996b), and campos rupestres in Central Brazil (Oliveira et al. 2015; Silveira et al. 2016). In these biodiversity hotspots, soil produced in old, climaticallybuffered landscapes (OCBILs) has undergone little rejuvenation over geological time scales (Hopper 2009), and the plant species in the communities have evolved a suite of adaptations to those P-impoverished conditions (Lambers et al. 2014). In south-western Australia, for example, the general relationship of increasing plant diversity with decreasing soil $\mathrm{P}$ concentrations can be observed at the regional scale (Lambers et al. 2010), but it is most pronounced for species with roots specialised for the acquisition of $\mathrm{P}$, with a variety of nonmycorrhizal species using a carboxylate-releasing Pmining strategy (Figs. 1a, b). Along a coastal dune chronosequence within the Southwest Australian hotspot, the same pattern of greater diversity of nonmycorrhizal species with decreasing $\mathrm{P}$ concentrations occurs (Zemunik et al. 2015, 2016) (Fig. 1c). This is a clear illustration of the point that soils in OCBILs are not uniformly old and nutrient-impoverished, and this juxtaposition of different soil ages/geologies has been linked to species turnover (Cowling et al. 2014).

The majority ( $>80 \%$ ) of vascular plant species form mycorrhizal symbioses (Brundrett 2009). Mycorrhizas are structures produced by associations of soil fungi and roots, and these specialised structures transfer poorlyavailable nutrients, especially $\mathrm{P}$, but also $\mathrm{N}$, that are acquired by mycorrhizal hyphae in soil to the plant; in return, the plant supplies the fungus with carbon compounds derived from photosynthesis (Brundrett 2009; Smith and Read 2008). Mycorrhizas allow plants to scavenge $\mathrm{P}$ that is in the soil solution beyond the zone that roots and root hairs can deplete. Many nonmycorrhizal species, in contrast, have evolved root specialisations that combine morphological and physiological adaptations (e.g., cluster roots and dauciform roots that release large amounts of carboxylates) capable of extracting all of their required nutrients from the soil without the use of mycorrhizas (Lambers et al. 2015d; 2008; Shane and Lambers 2005). Cluster-rooted plants 

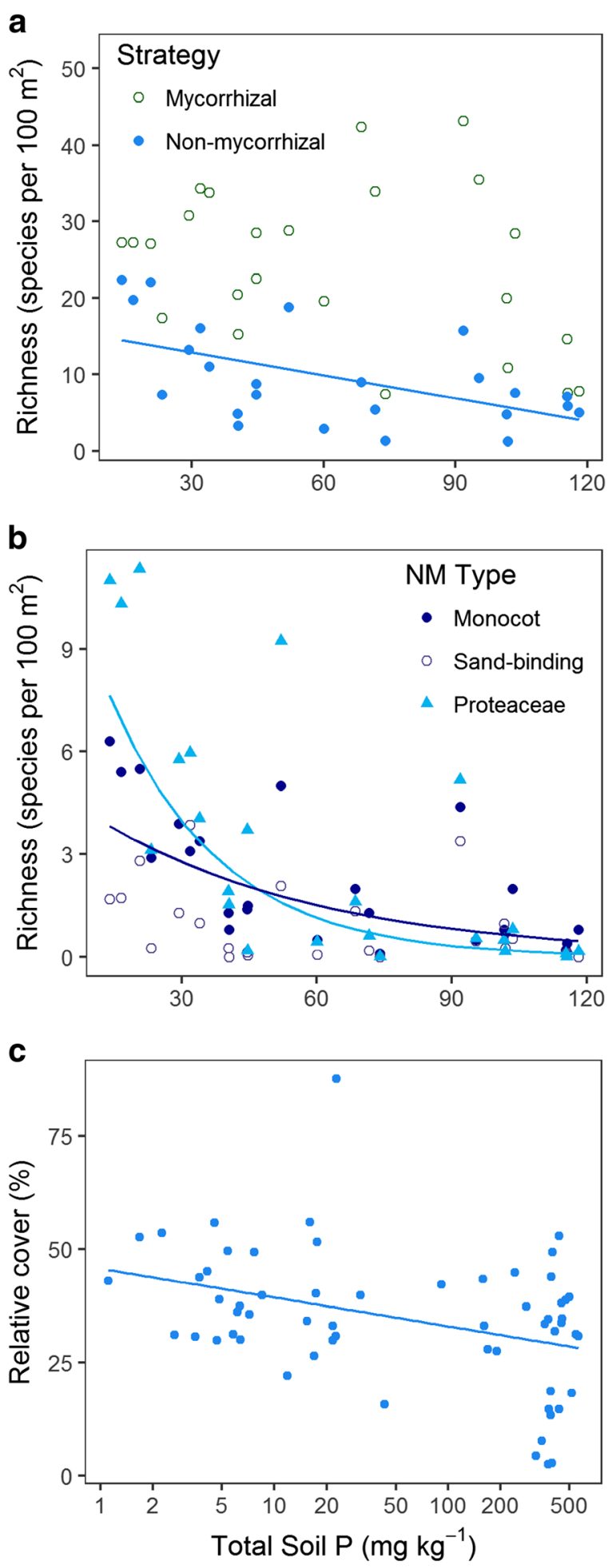

(e.g., Lupinus and Hakea species) efficiently mine P from P-impoverished soils by quickly producing
Fig. 1 (a) Species richness of mycorrhizal (open circles) and nonmycorrhizal (NM) plant species (filled circles) in relation to total soil phosphorus $(\mathrm{P})$ concentrations, from a comprehensive floristic survey of over 1000 quadrats in the wheatbelt of Western Australia by Gibson et al. (2004). (b) Species richness of three main NM species groups from the same floristic survey as in (a). (c) Relative canopy cover of NM species in relation to total soil $\mathrm{P}$ concentrations, from floristic survey plots within the Jurien Bay chronosequence (Zemunik et al. 2015). The log curve fits for the NM monocot and NM Proteaceae species were better by AIC than linear fits (AIC values: 64.3 versus 91.0 for the NM monocot species; 90.5 versus 121.5 for the NM Proteaceae species). Solid lines indicate significant $(P<0.05)$ regression relationships: (a) $P=0.006$; (b) $P=0.0007$ for monocot NM species, $P=0.0001$ for Proteaceae species; (c) $P=0.006$

clusters of fine, densely packed rootlets that release carboxylates in an 'exudative burst' to solubilise P that is tightly sorbed to soil particles (Lambers et al. 2008; Shane et al. 2004; Watt and Evans 1999). Mycorrhizas are an effective scavenging strategy for moderately infertile soils, but a carboxylate-releasing P-mining strategy is superior in severely P-impoverished soils (Lambers et al. 2008, 2015a) (Fig. 2). Yet, mycorrhizal species coexist with non-mycorrhizal species that release carboxylates on severely P-impoverished soils. In this review, we develop conceptual models explaining the coexistence of mycorrhizal and non-mycorrhizal species, with a focus on the roles of (i) belowground facilitation and (ii) interactions with root-associated soil biota, particularly mycorrhizal fungi and soil-borne pathogens.

Facilitation is a positive interaction that can occur between plants and results in an increase in species performance of at least one of the interacting species (Callaway 1995). Recent reviews of the available data show that facilitative mechanisms can contribute to the maintenance of biodiversity patterns globally (McIntire and Fajardo 2014; Peay 2016; Stachowicz 2001) and can also help better explain biodiversity-ecosystem function relationships across ecosystems (Wright et al. 2017). Both arbuscular mycorrhizas and ectomycorrhizas not only play a role in nutrient acquisition, but also in defence against pathogens (Marx 1972; Azcón-Aguilar and Barea 1997 Wehner et al. 2010). This has been known for a long time (Marx 1969), but its ecological implications are now receiving increasing attention (Maherali and Klironomos 2007; Sikes et al. 2009). The role of mycorrhizas in defence is not restricted to pathogens (Bennett et al. 2017; 
Fig. 2 Effects of carboxylates on mobilisation of phosphorus (P); other exudates may have similar effects, e.g., polygalacturonate (Nagarajah et al. 1970). Carboxylates (organic anions) are released via a carboxylate channel. The manner in which phosphatases are released is unknown. Carboxylates mobilise both inorganic $(\mathrm{Pi})$ and organic (Po) $\mathrm{P}$, which are both sorbed onto soil particles. At acid $\mathrm{pH}, \mathrm{Pi}$ and Po bind to oxides and hydroxides of iron (Fe) and aluminium (Al); at alkaline $\mathrm{pH}$, these compounds are precipitated by calcium $(\mathrm{Ca})$. The carboxylates effectively take the place of Pi or Po, thus pushing this into solution. The released phosphatase enzymes hydrolyse Po compounds, after they have been mobilised by carboxylates. For further explanation, see text; modified after Lambers et al. (2015c)

\section{CYTOSOL}

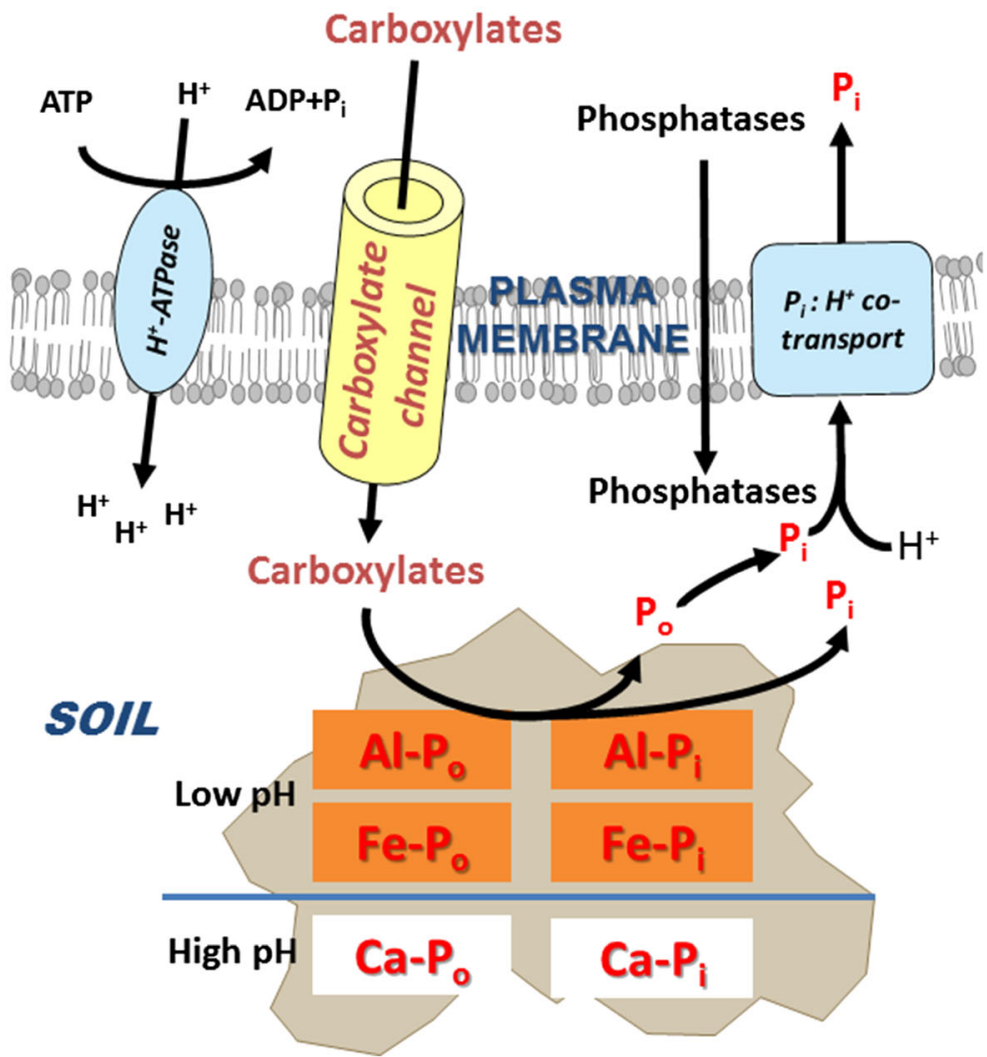

Cameron et al. 2013), but also includes protection against nematodes (Vos et al. 2013) and herbivores (Minton et al. 2016).

Several forms of mycorrhizal symbioses (e.g., arbuscular mycorrhizal (AM), ectomycorrhizal (ECM), ericoid and orchidaceous mycorrhizal) and nonmycorrhizal specialisations (e.g., cluster roots and dauciform roots) exist, with many of these occurring side-by-side, both within the same plant (Reddell et al. 1997; de Campos et al. 2013) and in neighbouring plants (Zemunik et al. 2015). The diversity of these Pacquisition strategies, like that of species diversity, often increases with decreasing $P$ availability (Lambers et al. 2008, 2014; Zemunik et al. 2015). This is puzzling, since the P-mining strategy is superior in severely Pimpoverished soils (Lambers et al. 2008). Despite a trend of decreasing richness and abundance of mycorrhizal plant species with declining soil P concentrations, mycorrhizal species do persist at relatively high abundances, even on the most severely P-impoverished soils (e.g., Lambers et al. 2014; Zemunik et al. 2015). Arbuscular mycorrhizal plant species, for example, remain abundant on the poorest soils (Zemunik et al. 2015), even though species of AM fungi investigated to date appear to have limited capabilities of accessing all pools of soil P (Yao et al. 2001; Smith et al. 2015). Is the $\mathrm{P}$ acquisition of mycorrhizal plants facilitated by growing in close proximity with specialised nonmycorrhizal neighbours? Is the success of nonmycorrhizal species compromised by greater susceptibility to pathogens, thereby preventing competitive exclusion? These pivotal questions are addressed in this review to provide answers to why high terrestrial plant diversity occurs on severely P-impoverished soils (Lambers et al. 2010). We develop an argument that a protective role of mycorrhizal fungi accounts for the very high plant species diversity in severely Pimpoverished landscapes (Laliberté et al. 2015; Teste et al. 2017). We explore this particular aspect throughout this review. 


\section{Mycorrhizal fungi}

The vast majority of empirical studies on mycorrhizal symbioses provide unequivocal evidence that these root symbiotic structures may enhance plant acquisition of poorly-mobile nutrients, especially $\mathrm{P}$ (Smith et al. 2015). The mycorrhizal symbioses achieve this primarily via their extraradical hyphae (ERH) that can scavenge poorly-available nutrients beyond root depletion zones ( $\mathrm{Li}$ et al. 1991a, b; Owusu-Bennoah and Wild 1979; Yao et al. 2001). Therefore, a vital component of mycorrhizal fungi are the ERH for both the plants and fungi, since it is the component that physically explores the soil matrix (Smith and Read 2008). When soil P availability is low, plants will allocate more resources to mycorrhizal fungi and their ERH, and alleviate soil nutrient limitations of plant growth (Smith and Read 2008).

Recently, Teste et al. (2016) reported on field experiments with fungal in-growth cores along a retrogressive 2 million-year old coastal dune chronosequence (Hayes et al. 2014; Laliberté et al. 2012), with the oldest soils along this sequence being some of the most severely Pimpoverished soils ever described (Turner and Laliberté 2015; Turner et al. 2017). Interestingly, these severely Pimpoverished soils show very high local plant species diversity, with a large proportion of non-mycorrhizal plant species (Zemunik et al. 2015, 2016). This chronosequence stretches inland over $10 \mathrm{~km}$ and represents one of the strongest natural soil fertility gradients that have been characterised. It exhibits a $\sim 60$-fold decline in total soil $\mathrm{P}$ concentration, and strong and clear shifts from $\mathrm{N}$ to $\mathrm{P}$ limitation of plant growth with increasing soil age (Laliberté et al. 2012; Turner and Laliberté 2015; Turner et al. 2017).

Teste et al. (2016) measured fungal biomass with key

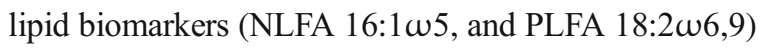
at three contrasting stages of soil development along this chronosequence. Sampling was done using closed, mesh and open (two no-core treatments: control and undisturbed) fungal in-growth cores during five months, including the wet winter months, which made it possible to study the dynamics of mycorrhizal fungal scavenging. Given the relatively high abundance of mycorrhizal species, surprisingly, there was consistently less AM and ECM fungal biomass in the oldest, most severely P-impoverished soils compared with that in the younger soils (Fig. 3a). This trend was found across all winter months (June, July and August) and at all levels of the core treatment except for the closed cores (Fig. 3a). Extraradical hyphal scavenging in these different-aged soils partly supported the trends found with the mycorrhizal fungal biomass data. In particular, it was found that there was significantly less AM fungal scavenging in the old soils compared with that in the young soils (Fig. 3b).

The findings of Teste et al. (2016) are intriguing. For the first time in a natural field study, mycorrhizal fungal biomass and the biomass of their ERH was found to be considerably less in the most severely P-impoverished soils, despite extensive root colonisation, high root biomass (Laliberté et al. 2017) and high abundance and diversity of mycorrhizal fungi (Krüger et al. 2015) and host plants (Zemunik et al. 2016). Teste et al. (2016) suggested that extremely low P availability in soil constrains ERH biomass, similarly to what Abbott et al. (1984) and Jones et al. (1992) found in detailed glasshouse studies with a range of soil P-levels. These findings also suggest that the productivity of mycorrhizal fungal ERH is limited by declining soil P availability, as well as declining soil $\mathrm{pH}$ (AM only). The results from this study support the conceptual framework proposed by Lambers et al. (2008) which argues that mycorrhizal species are less successful than carboxylate-releasing Pmining species in severely P-impoverished soils. However, that does lead to the question: why are there so many mycorrhizal plants, in terms of both species numbers and their cover on severely P-impoverished soils (Lambers et al. 2014; Zemunik et al. 2015, 2016)? We explore this question in the following sections, focusing on two possible, not mutually exclusive explanations: facilitation of mycorrhizal species by non-mycorrhizal species, and greater susceptibility of non-mycorrhizal plants to soil-borne pathogens.

\section{Facilitation}

Three broad facilitative mechanisms have been proposed: (i) indirect biotic facilitation; (ii) abiotic facilitation leading to nutrient enrichment (belowground facilitation for soil $\mathrm{N}$ and $\mathrm{P}$, and nutrient exchanges between plants); and (iii) classic abiotic facilitation leading to microclimate amelioration (Wright et al. 2017). Here, we briefly focus on reviewing the role of abiotic facilitative mechanisms, explaining how mycorrhizal species can benefit from the carboxylate-releasing P-mobilising non-mycorrhizal plants. Then we discuss biotic 


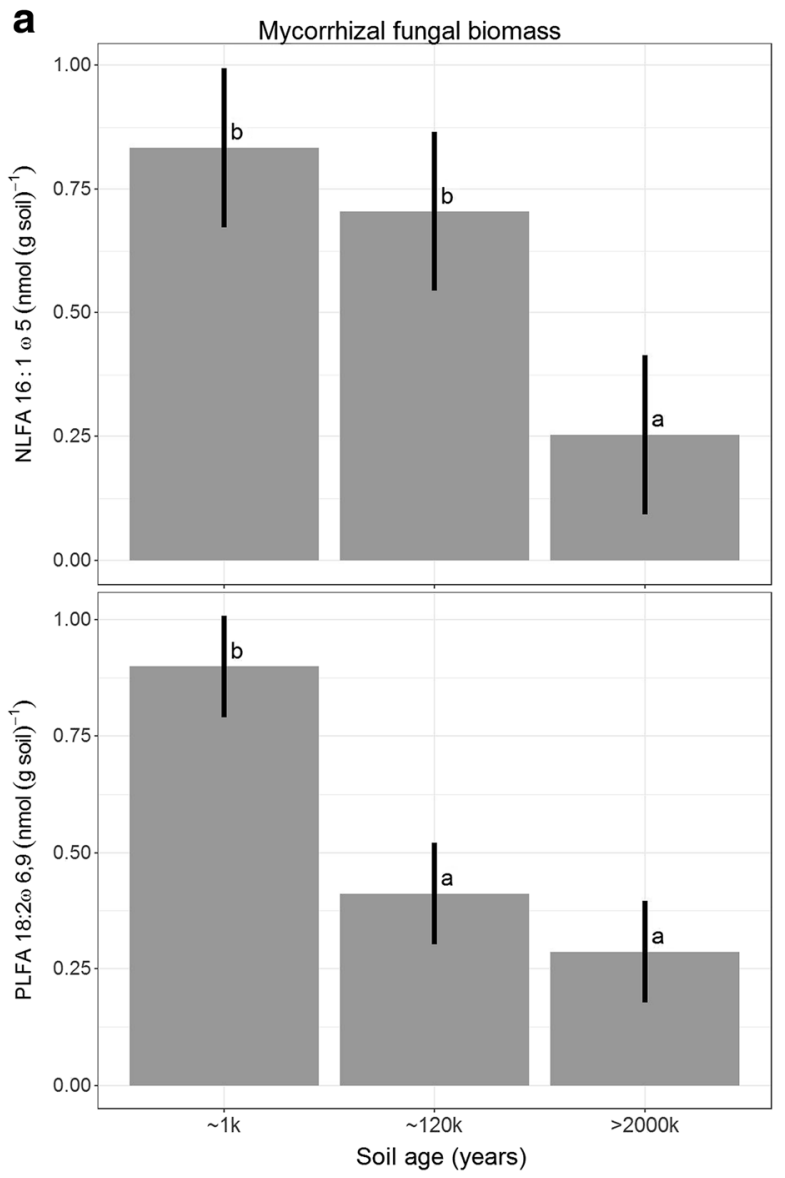

Fig. 3 (a) Mycorrhizal fungal biomass in soils of different ages along the Jurien Bay chronosequence as measured with the neutral lipid fatty acid (NLFA) biomarker (16:1 155$)$ a proxy for arbuscular mycorrhizal (AM) fungi, and the phospholipid fatty acid (PLFA) biomarker $(18: 2 \omega 6,9)$ a proxy for ectomycorrhizal (ECM) fungi. Fungal biomass was measured with the fungal in-growth core treatments allowing root and hyphal infiltration (i.e. all except the PVC treatment following Teste et al. (2016) during the winter

mechanisms (see sections on pathogens below) for maintaining biodiversity.

Soil nutrient enrichment that results from belowground facilitation has been well documented in ecosystems inhabited by plants whose productivity is more limited by $\mathrm{N}$ than by any other nutrient (Wright et al. 2017). In particular, positive effects of legumes and their associated $\mathrm{N}_{2}$-fixing biota on local soil nutrient enrichment and the growth of neighbouring plants have been demonstrated (Vitousek et al. 2013). However, nonlegume nutrient enrichment such as enhanced $\mathrm{P}$ mobilisation, due to the production of nutrientmobilising root exudates (Lambers et al. 2013; Li et al.

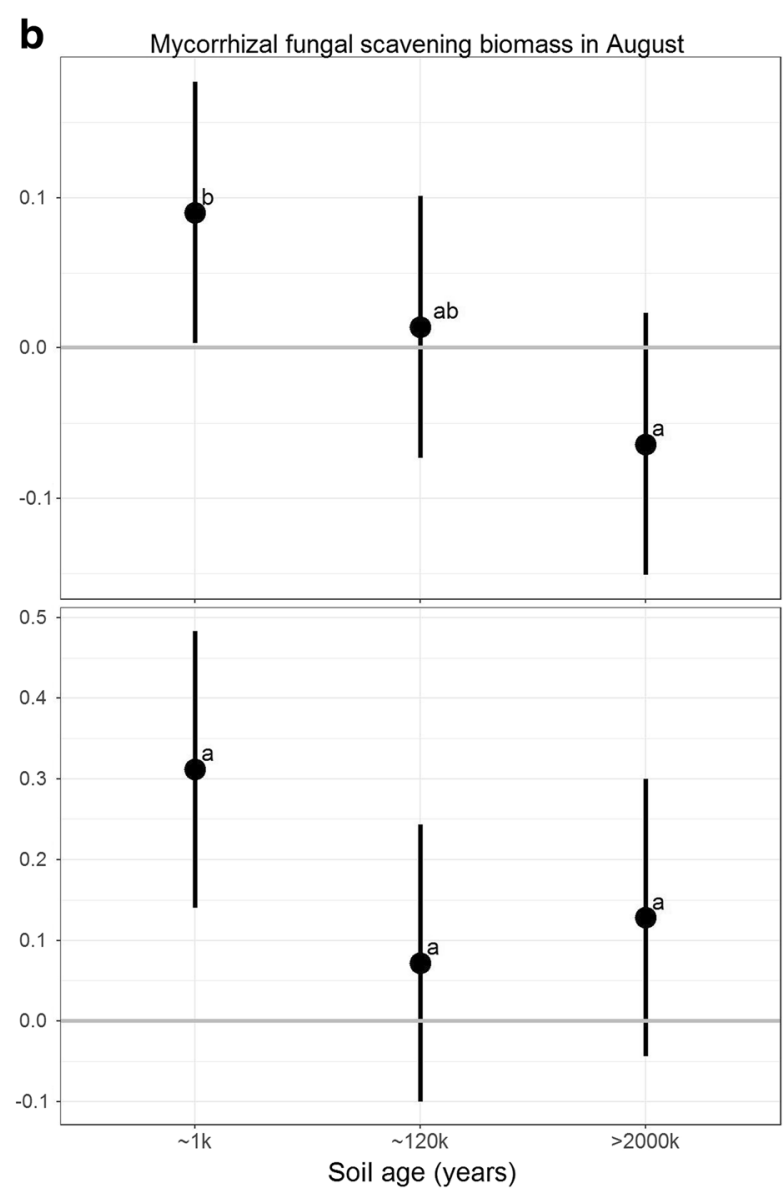

months (June, July, August) at Jurien Bay. (b) Mycorrhizal fungal scavenging as expressed as biomass differences between the mesh and PVC core treatments in August at the end of the winter (Teste et al. 2016). This is a reanalysis of data from Teste et al. (2016). Percent root colonisation by AM showed a significant humpshaped pattern along soil age, where colonisation levels were low in the oldest soils (Teste et al. 2016) partly supporting the biomass responses in $(a)$ and $(b)$

2007), has not received as much attention, and few studies have assessed if these enrichments are ecologically important.

We propose a number of hypotheses that could be tested in model systems such as hyperdiverse shrublands in South Africa (Cowling and Richardson 1995; Cowling et al. 1996a) and Australia (Lamont et al. 1977; Lambers et al. 2014) that host both N- and P-impoverished soils (i.e. where either $\mathrm{N}$ or $\mathrm{P}$ limit plant productivity), and also in other old, climaticallybuffered, infertile landscapes, such as the campos rupestres of Brazil (Oliveira et al. 2015; Silveira et al. 2016), South America's Pantepui (Hopper 2009), and 
parts of the pampas in southern South America (Sainz Rozas et al. 2012; Hopper et al. 2016).

Nutrient mobilisation-based facilitation

Nutrient mobilisation-based facilitation in crop plants is not only relevant for soil macronutrients such as $\mathrm{P}$, but also for micronutrients such as iron (Fe), zinc $(\mathrm{Zn})$ and manganese $(\mathrm{Mn})$, since these nutrients are also mobilised by cluster-rooted plants ( $\mathrm{Li}$ et al. 2014). Therefore, this process can improve uptake of these nutrients by neighbouring non-mobilising species provided their root systems are sufficiently close at the time the nutrients have been made available. Plant-based mechanisms underpinning this type of facilitation may involve the release of large quantities of acid phosphatases, protons, carboxylates and chelating substances from roots which increases the concentration of $\mathrm{P}$ and other nutrients in the soil solution (Li et al. 2007; Lambers et al. 2013). Recent microcosm studies support this contention, since it was found that nutrient-mobilisation facilitation occurs and improves plant growth (Muler et al. 2014; Teste et al. 2014). We surmise that nutrient-mobilisation facilitation in natural ecosystems may be more common than previously thought (Li et al. 2014; Wright et al. 2017); this hypothesis requires more formal testing as proposed in this review (Fig. 4).

Since soil N and P supply changes drastically with time after fire (Certini 2005), we expect that changing fire regimes due to climate change will alter plant belowground strategies for $\mathrm{N}$ and $\mathrm{P}$ acquisition in speciesrich ecosystems (Fig. 5). Belowground facilitation is also predicted to play an increasingly important role in mediating the negative impacts of harsher environmental conditions due to global climate change (Brooker et al. 2008). Since more frequent fires and less annual precipitation (Williams and Bradstock 2008; Indian Ocean Climate Initiative 2012) are predicted to occur in south-western Australia, we therefore expect that belowground facilitation, for $\mathrm{N}$ and $\mathrm{P}$ acquisition in particular, will play an increasingly important role in the maintenance of biodiversity in these ecosystems.

Nutrient exchange-based facilitation

Plants have evolved diverse strategies to gather soil nutrients and the high functional diversity in severelyimpoverished soils was suggested to be linked to high species richness in shrublands of Australia and South
Africa (Lamont 1982). These belowground nutrientacquisition strategies interact when different plant species grow close to each other ( $\mathrm{Cu}$ et al. 2005; Gardner and Boundy 1983; Horst and Waschkies 1987; Orians and Milewski 2007). Indeed, plants are capable of exchanging (i.e. 'sharing') nutrients with their neighbouring plants via root intermingling or mycorrhizal networks (Teste et al. 2009, 2014, 2015; Jakobsen and Hammer 2015; Simard et al. 2015). While microcosm studies show clear evidence for facilitation (Muler et al. 2014; Teste et al. 2014), further work is required in natural ecosystems. So far, we do not yet know whether ecologically relevant amounts of $\mathrm{P}$ or micronutrients exchange between non-mycorrhizal and mycorrhizal plants during the cluster-root exudative 'burst', where neighbouring mycorrhizal plants could take advantage of this sudden mobilisation of nutrients (Gardner et al. 1983; Lambers et al. 2013; Muler et al. 2014; Teste et al. 2014).

Belowground nutrient exchanges are likely initiated early after fire, and we hypothesise that plants acting as so-called 'nutrient-donor plants' (Fig. 4) are determined by soil nutrient availabilities that vary with time since fire (Certini 2005). Thus, the relative importance of $\mathrm{N}$ and $\mathrm{P}$ exchanges is also expected to vary with time after fire (Fig. 5), because $\mathrm{N}$ levels in the soil build up as a result of an abundance of $\mathrm{N}_{2}$-fixing plants (i.e. legumes, actinorhizal species and cycads) that effectively fix atmospheric $\mathrm{N}_{2}$ and release some of that $\mathrm{N}$ to the soil (DeLuca et al. 2008; Halliday and Pate 1976; Hansen and Pate 1987; Wall 2000). For example, within the first two years after fire, at least $1 \mathrm{~kg} \mathrm{ha}^{-1} \mathrm{yr}^{-1}$ of $\mathrm{N}$ can be fixed by $\mathrm{N}_{2}$-fixing plants such as Acacia species (Hingston et al. 1982), and $\sim 10 \%$ of this fixed $\mathrm{N}$ can be transferred between plants based on interplant $\mathrm{N}$ transfer studies (He et al. 2009). However, the ability to fix $\mathrm{N}_{2}$ strongly depends on $\mathrm{P}$ availability, since $\mathrm{N}_{2}$ fixation is a process requiring substantial amounts of $\mathrm{P}$ (Raven 2012; Valentine et al. 2017; Vitousek et al. 2002). A few years ( $>5$ ) after fire, soil $P$ becomes less available, and the abundance of $\mathrm{N}_{2}$-fixing plants declines (Fig. 5); however, they are not excluded from the system (Pate and Beard 1984), and they may benefit from and be sustained by interactions with P-mining plants (Fig. 5). As proposed by Power et al. (2010), a P-availability threshold likely exists for the $\mathrm{N}_{2}$-fixing plants. Therefore, we suggest that when the soil has a low N:P ratio, $\mathrm{N}_{2}$-fixing plants are most abundant with high species richness (Fig. 5), and propose that a $\mathrm{P}$ 
Fig. 4 Hypothesised nutrient exchanges between neighbouring 'nutrient-donor' plants; (a) shortly after fire and (b) $\sim 10$ years after fire. Relative abundance and importance of the exchanges and pathways are shown with increasing font and arrow width. *Importance varies with distance to neighbour and mass flow is pervasive, but not considerable in most soils. Shortly after a fire, $\mathrm{N}_{2-}$ fixing plants ultimately benefit more than P-mining plants, since they would grow even faster in the presence of the interactions outlined in (a). Some time after fire ( $>10$ years), a different set of interactions is expected to lead to more benefits and faster growth by the P-mining plants, as outlined in (b)
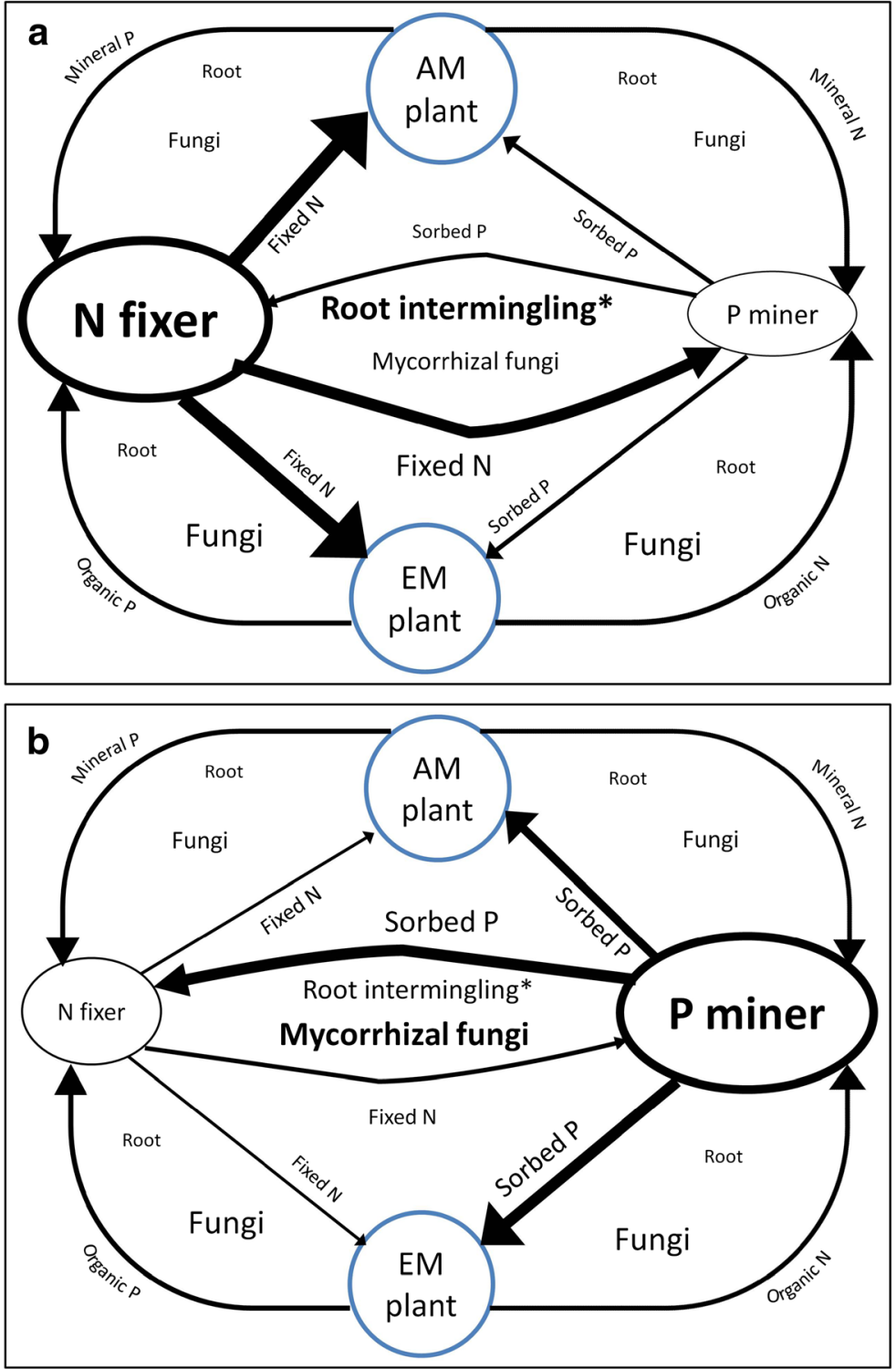

availability threshold exists for the $\mathrm{N}_{2}$-fixing plants to successfully remain competitive over other species (Pekin et al. 2011). Legume species that co-occur with P-mining species must obtain enough $\mathrm{P}$ to avoid competitive exclusion, but the mechanisms allowing coexistence with surrounding plants are not fully understood and require further testing (Figs. 4, 6).

In the case of P-mining plants, shortly after fire $(<$ 5 years), these plants become enriched in ${ }^{15} \mathrm{~N}$, resembling more closely that of the atmosphere, thus possibly resulting from exchanges of $\mathrm{N}$ with $\mathrm{N}_{2}$-fxing plants (Schmidt and Stewart 1997). However, it is not known how relevant belowground nutrient exchanges are in this process and what the $\mathrm{N}$ sources are (Schmidt and Stewart 1997). We hypothesise that P-mining plants benefit from $\mathrm{N}$-nutrient exchanges with the abundant $\mathrm{N}_{2}$-fixing plants (Figs. 4,6 ), and later (> 5 years after fire) they can contribute to maintaining the $\mathrm{N}_{2}$-fixing plants in the system via P-nutrient exchanges (Fig. 4). Co-occurrence of P-mining and $\mathrm{N}_{2}$-fixing plants on a site is common after fire and some species are often found growing in close proximity where roots and their mycorrhizal fungi can interact (Fig. 6). Furthermore, the soil $\mathrm{N}$ concentrations shortly after fire can be spatially variable (Hopmans et al. 2005), where $\mathrm{N}_{2}$-fixing plants may form small $\mathrm{N}$-rich patches for neighbouring plants. 


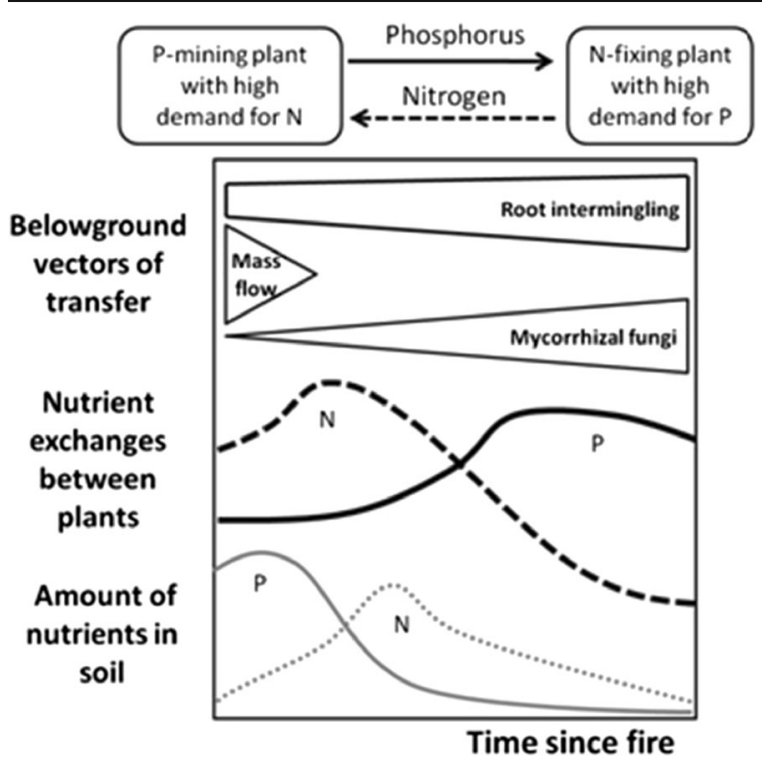

Fig. 5 Source-sink relationships and soil nitrogen $(N)$ and phosphorus $(\mathrm{P})$ levels as drivers of nutrient exchanges between plants with time after fire. Belowground vectors of transfer are mechanisms that may operate and vary in importance with time since fire. Mass flow (mostly for N, but also for P in very sandy soils and high-rainfall environments (Huang et al. 2017)) is likely prominent soon after fire following significant rain. Root intermingling plays a role throughout, especially for species growing in close proximity. Mycorrhizal fungi and the formation of mycorrhizal networks become pivotal for exchanges later when the fungal communities have completely re-established. In general, arbuscular mycorrhizal (AM) and ectomycorrhizal (EM) fungal abundance is reduced shortly after fire, and subsequent recovery with time and litter accumulation occurs without any long-term effects on colonisation or spore abundance (McMullan-Fisher et al. 2011). The availability of $\mathrm{N}$ and $\mathrm{P}$ generally follow the pattern shown here, but is mainly dependent on fire intensity (Burrows and Wardell-Johnson 2003)

Similarly, P-mining plants may form ephemeral 'available-P' patches for neighbouring plants.

Various legume species in south-western Australia form both $\mathrm{AM}$ and ECM along with $\mathrm{N}_{2}$-fixing nodules (Albornoz et al. 2016a; Brundrett 2009; Png et al. 2017), giving rise to the possibility for an elaborate guild of structures for nutrient exchanges between plants that have never been documented (Fig. 4). We further hypothesise that belowground nutrient exchanges may also promote plant species coexistence via resource sharing that may form the basis for indirect resource partitioning, such as belowground interactions between $\mathrm{N}_{2}$-fixing plants and P-mining plants (Fig. 4). However, to establish how these facilitative mechanisms remain ecologically and evolutionarily stable will require further study.
Source-sink relationships have been used to conceptualise the potential flow of nutrients through mycorrhizal fungi from plants with greater nutrient levels to plants with lower nutrient levels (Simard et al. 2012). Soon after fire, $\mathrm{N}_{2}$-fixing plants have a high demand for P-demanding molecules (e.g., ATP and rRNA for making nitrogenase) for symbiotic $\mathrm{N}_{2}$-fixation (Raven 2012; Paul 2014). These $\mathrm{N}_{2}$-fixing plants are $\mathrm{P}$ sinks at this early stage, and may meet their $\mathrm{P}$ requirements with the help of scavenging mycorrhizal hyphae and/or the intermingling of roots around cluster roots of neighbouring P-mining species (Teste et al. 2014). Such scavenging may represent an efficient strategy for obtaining $\mathrm{P}$ in extremely P-impoverished soils; legumes also show higher root phosphatase activity than co-occurring non-legume species, suggesting that they are particularly good at acquiring organic P (Png et al. 2017). Both AM and EM fungi could access newly mobilised P from cluster root 'burst' microsites, but EM may be favoured, since they possess highaffinity $\mathrm{P}$ transporters at their mycelia front (Cairney 2011). Phosphorus-mining plants, in contrast to $\mathrm{N}_{2^{-}}$ fixing plants, may act as $\mathrm{N}$ sinks shortly after fire, due to the $\mathrm{N}$ losses during fire (Wittkuhn et al. 2017). These $\mathrm{N}$ demands could be offset by transfer of $\mathrm{N}$ from $\mathrm{N}_{2}$-fixing plants (Fig. 4). Root intermingling could allow $\mathrm{N}$ to move between roots, due to leakage and/or root turnover, ultimately raising the possibility of $\mathrm{N}$ transfer from $\mathrm{N}_{2}$-fixing plants to P-mining plants (Fig. 4). There is great potential for discovering an impressive array of unique belowground root interactions geared to promoting plant coexistence and retaining nutrients in these ecosystems.

Concluding remarks on belowground facilitation and the maintenance of biodiversity

Local plant species coexistence and the maintenance of biodiversity in nutrient-poor ecosystems can be promoted by a multitude of interacting mechanisms such as resource partitioning (McKane et al. 2002; Turner 2008), plant-soil feedback (Teste et al. 2017), degree of dependency on mycorrhizal fungi (Hart et al. 2003), or as proposed here, by way of belowground facilitation due to complementary nutrient-acquisition strategies and nutrient exchanges. 


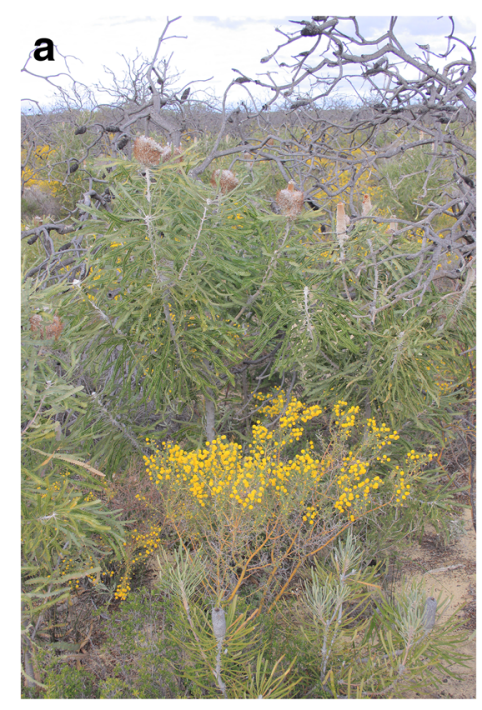

Fig. 6 (a) Acacia pulchella (Fabaceae, producing nitrogen-fixing root nodules) with yellow flowers, together with Banksia species (Proteaceae, producing phosphorus-mobilising cluster roots), B. attenuata (foreground) and B. prionotes (background) or (b)

\section{The role of mycorrhizas in defence against pathogens}

Nutrient uptake is widely accepted as the primary role of mycorrhizal fungi in contributing to plant fitness (Smith et al. 2015). However, increasing evidence over the last few decades has shown that mycorrhizas can also offer their hosts defence against pathogens (Marx 1972; Maherali and Klironomos 2007; Sikes et al. 2009; Wehner et al. 2010; Albornoz et al. 2016b). They can provide physical barriers around roots against soil-borne pathogens (Marx 1972), produce antimicrobial compounds (Duchesne et al. $1988 \mathrm{a}, \mathrm{b})$, or neutralise the negative effects of pathogens for seedling survival and growth (Liang et al. 2015). In this section, we summarise the current evidence of pathogen defence of both ECM and AM fungi, and discuss their implications for plant-plant interactions in hyperdiverse ecosystems.

\section{Mechanisms of pathogen defence}

There are several mechanisms by which mycorrhizal fungi provide defence against pathogens to their hosts that are not necessarily mutually exclusive (Sikes et al. 2009). They do, however, seem to differ between ECM and AM fungi. Both ECM and AM fungi can competitively exclude pathogenic organisms from roots and the rhizosphere, and induce changes in the root system (Marx 1972; Pozo et al. 2002; Wehner et al. 2010). For example, ECM fungi develop a hyphal mantle around their roots tips that acts as a physical barrier (Marx 1969; Branzanti et al. 1999), while AM fungi can induce production of root callose around infected root cells (Pozo et al. 2002). On the other hand, while ECM fungi can produce a vast number of antibiotic compounds (Marx 1972; Strobel and Sinclair 1991), there is as yet no evidence that AM fungi produce such compounds. However, there is evidence that AM fungi modify the microbial community in the rhizosphere, favouring organisms capable of producing such antibiotics (Wehner et al. 2010).

The extent of the protection offered by mycorrhizas also differs between ECM and AM fungi. The protection provided by ECM fungi to roots against pathogens tends to be localised (Marx 1972). That is, within the same plant, non-mycorrhizal roots can be more susceptible to infection than ECM roots of the same plant (Marx 1972). On the other hand, AM fungi can provide not only localised protection, but they can also induce systemic resistance (Pozo et al. 2002). For example, a split-root experiment conducted by Pozo et al. (2002) evaluated the role of AM fungi in protecting tomato plants against the oomycete Phytophthora parasitica. They found local production of protective enzymes by AM-colonised roots, and these enzymes were also 
found in non-mycorrhizal roots of the same individual. Additionally, Herre et al. (2007) showed that colonisation by AM fungi can offer systemic protection against the foliar pathogen Phytophthora palmivora. We infer that a small amount of AM root colonisation could be sufficient to offer a systemic defence against pathogens, while the pathogen susceptibility of the ECM hosts is negatively and directly related to the amount of ECM root colonisation.

Since mycorrhizal symbiosis depends on soil fertility (Smith and Read 2008), the protection against pathogens offered by mycorrhizas is potentially context-dependent, and thus, pathogen susceptibility can also depend on soil properties. Several studies have shown the effects of soil nutrients, $\mathrm{pH}$ and moisture on both the amount of root colonisation and mycorrhizal community composition (Krüger et al. 2015; Schappe et al. 2017). Neighbouring plants in a community can also have strong effects on root colonisation by mycorrhizal fungi (Dickie et al. 2004; Kennedy et al. 2012; Teste et al. 2014). Furthermore, different mycorrhizal fungal species can produce contrasting antibiotic compounds or mantle structures (Marx 1972), and, hence, offer different levels of root protection. Therefore, altering mycorrhizal fungal communities can potentially have strong effects on the way in which hosts respond to pathogen infections.

\section{Susceptibility to pathogens: the role of suberised endodermis and exodermis}

A major role of plant roots is the uptake of nutrients and water from soil (Marschner 1995; Steudle and Peterson 1998). Simultaneously, they must be able to exclude potentially harmful substances and prevent the entry of pathogens into the roots. This selectivity in root function is accompanied by a complex root anatomy (Esau 1977; Schreiber et al. 1999). However, our knowledge of the anatomy of Proteaceae roots is scarce. Here, for the first time, we discuss comparative detailed anatomical structures for three selected Proteaceae species, all endemic to south-western Australia, and all producing roots with specialised P-mining clusters: harsh hakea (Hakea prostrata) and acorn banksia (Banksia prionotes), which both grow in weathered soils and seasonally-dry environments, and river banksia (Banksia seminuda), which also grows in weathered soils, but in high-rainfall zones.
Detailed anatomical and histochemical studies of Proteaceae roots reveal species-specific differences. Soil-grown $H$. prostrata roots develop an early endodermis (internal sheath) with a complete ring of suberin lamellae as early as $20 \mathrm{~mm}$ from the apex; however, at this stage, the root does not have an exodermis (external sheath; Fig. 7a). This strongly suberised internal sheath isolates the stele from the rest of the root, and is likely the main barrier against pathogen invasion into the xylem and spread throughout the plant. At $50 \mathrm{~mm}$ from the apex, roots develop a patchy exodermis in which some cells do not develop suberin lamellae, and continue to grow as 'passage cells' (Fig. 7a). This patchy exodermis is unlikely to be an efficient barrier against pathogen invasion into the root. At this stage, roots have a strongly-suberised and complete endodermis without passage cells. In the stele, strongly-lignified penta-poler xylem vessels are apparent, which is different from typical tetra-poler dicotyledonous xylem vessels (Esau 1977). Extra xylem poles likely provide an extra path for transport of water and minerals, which radially move from the soil into the stele (Fig. 7a).

The structure of $B$. prionotes and B. seminuda roots differs from that of $H$. prostrata. While weakly-developed, an incomplete endodermis is apparent in B. prionotes at $20 \mathrm{~mm}$ from the apex; brighter stains in the cell walls of inter-xylem poles reveal a stronger endodermis in B. seminuda (Fig. 7a). At $50 \mathrm{~mm}$, the endodermis of $B$. prionotes has relatively strong suberin depositions with bright stains compared with the younger zone, yet it is not complete. Some endodermal cells near the xylem poles remain as passage cells without depositing suberin lamellae. These cells may provide an easy path that has low resistance for water and nutrient transport into the xylem. However, as roots age, more passage cells deposit suberin lamellae, and thus their numbers decline (Enstone et al. 2003). In contrast to $B$. prionotes, B. seminuda roots develop a strongly suberised, complete ring of endodermis, which is similar to that in H. prostrata (Fig. 7a). Both Banksia species do not develop a suberised exodermis up to $50 \mathrm{~mm}$ behind the root tip, which is different from $H$. prostrata. Absence of a suberised exodermis indicates (1) lack of filtration of ions from the soil solution, (2) low resistance for radial water transport from the soil solution into the root, (3) rapid carboxylate exudation (citrate and malate) from roots into the rhizosphere to first solubilise and then absorb sparingly-soluble mineral nutrients, especially $\mathrm{P}$ (Lambers et al. 2015b; Shane and Lambers 2005). 
a

H. prostrata

B. prionotes

B. seminuda

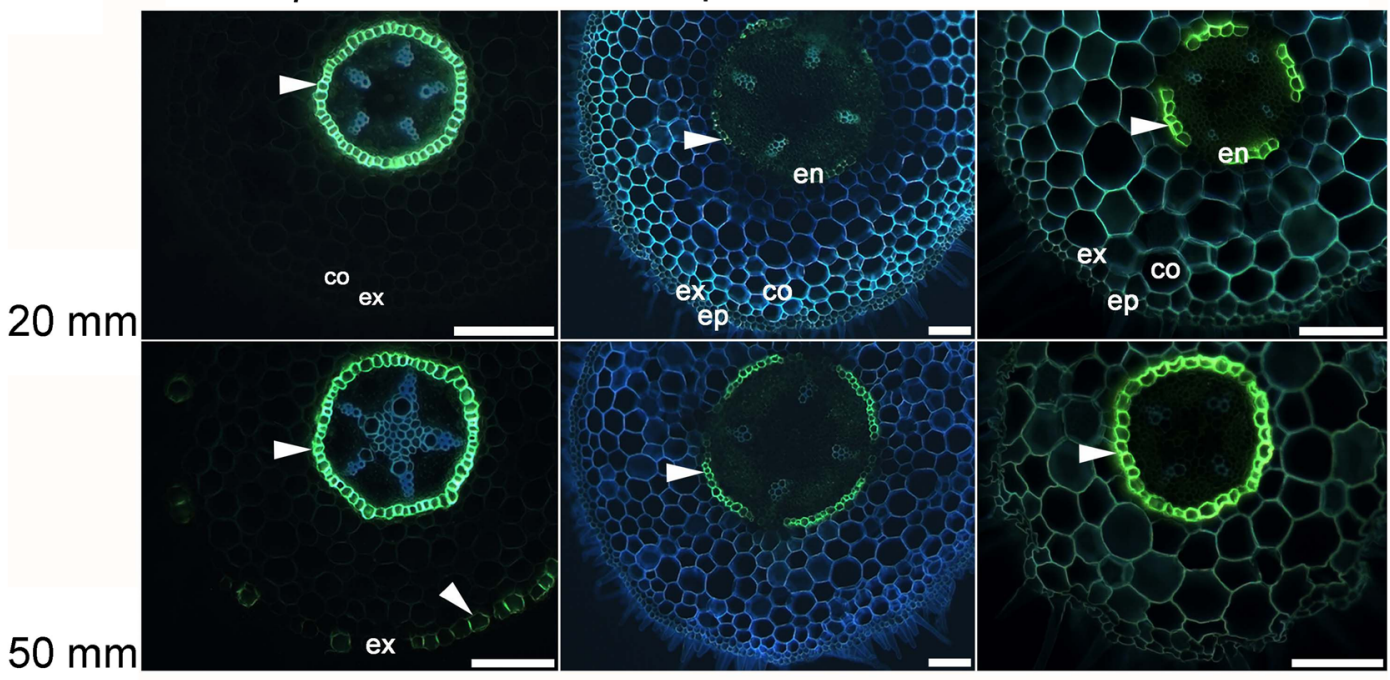

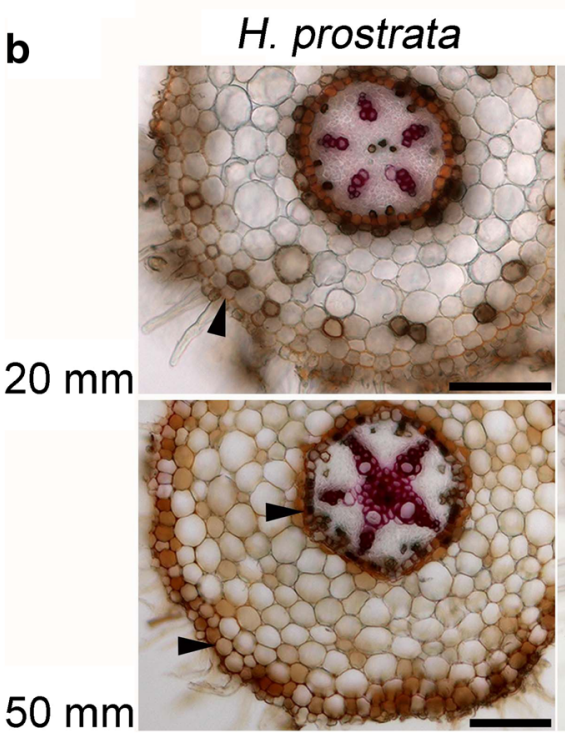

$50 \mathrm{~mm}$

Fig. 7 Deposition of suberin (a) and lignin (b) in roots of Hakea prostrata, Banksia prionotes growing on the Jurien Bay sand dunes on the west coast of south-western Australia, and $B$. seminuda growing on the Warren sand dunes on the south coast of south-western Australia. Roots of $H$. prostrata and B. prionotes were collected at the end of the dry season (April), seedlings of $B$. seminuda were collected in December and grown in pots in a
B. prionotes

B. seminuda
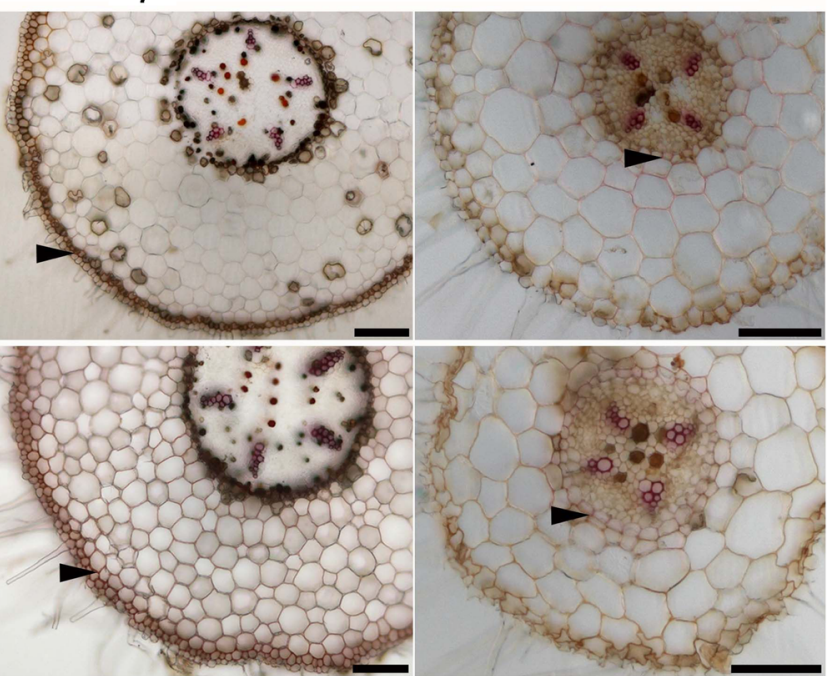

garden till February. Cross-sections were taken at $20 \mathrm{~mm}$ and $50 \mathrm{~mm}$ from the apex of a non-cluster root and stained with fluorol yellow 088 or phloroglucinol. The presence of suberin lamellae was detected by yellow-green fluorescence (white arrowheads); the presence of lignin was detected by orange-red staining (black arrowheads). Bars $=100 \mu \mathrm{m}$

Not only Proteaceae, but also Fabaceae such as Lupinus angustifolius, L. luteus, Cicer arietinum and Glycine max, lack a suberised exodermis in their roots, even under stressful culture conditions (Bramley et al. 2009; Hartung et al. 2002; Perumalla et al. 1990; Ranathunge et al. 2008). Most of these Fabaceae, as well as many other Fabaceae, are known to release large amounts of carboxylates (Pearse et al. 2006; Veneklaas et al. 2003). On the other hand, monocots such as Oryza sativa, Saccharum officinarum, Triticum aestivum and Zea mays do produce a suberised exodermis (Clark and Harris 1981; Perumalla and Peterson 1986; Perumalla et al. 1990). Monocots that have been studied often release some specific exudates, but do not release large amounts of carboxylates, unlike many Proteaceae and Fabaceae (Delhaize et al. 1993; Li et al. 2013; Ma et al. 
2003; Oburger et al. 2014; Pearse et al. 2006; Sun et al. 2016). There is good information on angiosperm species in specific families that do or do not produce an exodermis; the vast majority of angiosperms does produce an exodermis (Perumalla et al. 1990). However, there is a distinct lack of knowledge on the carboxylate exudation or leaf manganese concentrations, which can be used as a proxy for carboxylate concentrations in the rhizosphere (Lambers et al. 2015c) of angiosperms of which we know the root structure. We surmise that species that release large amounts of exudates have evolved to strategically modify their root structure for rapid carboxylate exudation in order to efficiently take up $\mathrm{P}$ from nutrient-poor soils. This hypothesis requires further testing involving a wider range of plant families.

Absence of a suberised exodermis may have some negative consequences, such as (1) provide easy access for pathogens to enter into the root, and (2) loss of water and nutrient ions from the roots to the dry soil by backflow (Hose et al. 2001; Ranathunge et al. 2008; Thomas et al. 2007). In some plant species, such as Glycine max (soybean), 'diffuse suberin' in the epidermal cell walls fulfils the requirement of an exodermis, which is lacking in soybean. Diffuse suberin in the epidermis acts as a physical and chemical barrier for the penetration of Phytophthora sojae, an oomycete causing soybean root rot disease (Ranathunge et al. 2008). However, there is no histochemical evidence indicating the presence of 'diffuse suberin' in the epidermal cell walls of Banksia species studied so far. Instead, they exhibit intense deposition of phenolic compounds in the cell walls of the entire cortex, as indicated by bright autofluorescence (Fig. 7a). Such soluble phenolic compounds, which are associated with the suberin polymer, are known to act as antifungal agents (Biggs and Miles 1988; Kolattukudy 1984; Lulai and Corsini 1998; Thomas et al. 2007). The presence of a suberised endodermis, on the other hand, serves as the last line of defence before pathogens invade the vascular cylinder and spread throughout the plant (Enkerli et al. 1997; Enstone et al. 2003; Huitema et al. 2004; Kolattukudy and Espelie 1989; Thomas et al. 2007).

Not only suberin but also lignin, another complex aromatic polymer, which is deposited in the secondary cell walls of all vascular plants, plays a major role in defence against abiotic and biotic stresses, especially against pathogens and insects (Bonawitz and Chapple 2010; Moura et al. 2010). Lack of suberin in the exodermis of $B$. prionotes is associated with depositing more lignin into the exodermal cell walls (subepidermal cell layer) than in the two other species (Fig. $7 b)$. This modification would be expected to have positive adaptive functions, especially against pathogens. Lignin acts as a non-degradable 'physical barrier' with inter-monomeric C-C linkages that inhibit fungal pathogen penetration into the root (Lygin et al. 2009; Moura et al. 2010; Richter 1996). Thus, lignification of the exodermis would certainly reduce the risk of being vulnerable to pathogen attack. In contrast, $H$. prostrata and $B$. seminuda, which contain a strongly developed and completely suberised endodermis show weak lignification in the exodermis (Fig. 7). However, certain exodermal cell walls of $H$. prostrata also show mild staining for lignin, perhaps by developing tertiary cells walls, but not as pronounced as in B. prionotes (Fig. 7b).

The anatomical studies of roots of three Proteaceae species show that, remarkably, none of them forms a complete suberised exodermis. Similar observations have been made for Fabaceae. Lack of this important feature in Proteaceae and Fabaceae roots may be an adaptive trait enabling rapid carboxylate exudation into the rhizosphere and acquisition of scarcely available nutrients from severely-impoverished soils in southwestern Australia. However, the absence of an exodermis makes roots more vulnerable and susceptible to soilborne pathogens. Taken together, these observations suggest that root anatomical adaptations for efficient nutrient acquisition from severely P-impoverished soils trade-off against root defence against soil-borne pathogens.

\section{Soil-borne pathogens and negative density dependence}

Soil-borne pathogens are often considered as a threat to native plant diversity in natural ecosystems. This view is based mostly on research that has studied the ecological impacts following the introduction of exotic, virulent soil-borne pathogens into new ecosystems. For example, the introduced oomycete Phytophthora cinnamomi has major negative impacts on plant biodiversity in south-western Australia, because a large number of native plant species are highly susceptible to it, leading to 'dieback' (Coates et al. 2014; Shearer et al. 2004). However, the traditional view of soil-borne pathogens as 'threats' to biodiversity has been gradually changing, as it is now recognised that native, less virulent pathogens 
that have co-evolved with a given flora can actually play a positive role in the maintenance of local plant species diversity (Bever et al. 2015).

How can soil-borne pathogens possibly contribute to local plant species coexistence? One explanation is a process termed 'negative conspecific density dependence', whereby plants suffer disproportionately from being exposed to a high density of conspecific neighbours (Terborgh 2012) (Fig. 8). This could be due to the build-up of root pathogens, when conspecific plant density increases, with these pathogens having either hostspecific effects or stronger negative effects on conspecific individuals than individuals of other plant species. Although this idea has recently seen a 'renaissance' in plant ecology (Bever et al. 2015), it dates back to the work of Gillett (1962) on the ecological importance of pests. Later, the idea that pests could promote local plant diversity through negative conspecific density dependence was formalised by Janzen (1970) and Connell (1971) as an explanation for high tree species diversity in tropical rainforests.

More recently, pathogen-mediated negative density dependence was taken out of its initial tropical rainforest context, and touted as a possible explanation for the high local plant diversity in south-western Australian shrublands (Laliberté et al. 2015). At first glance, these seasonally-dry shrublands are quite different from species-rich tropical rainforests, but both tend to occur on old, strongly-weathered soils where soil P availability is very low. Laliberté et al. (2015) hypothesised that such strong P limitation of plant growth in these ecosystems influences plant susceptibility to root pathogens, because many root traits that enable efficient $\mathrm{P}$ acquisition from P-poor soils (e.g., high specific root length, high root density, lack of suberised exodermis) trade-off against root longevity and defence to soilborne pathogens (Laliberté et al. 2015). Consequently, it was suggested that non-mycorrhizal, cluster-rooted Proteaceae in P-impoverished shrublands from southwestern Australia might be particularly efficient at mobilising $P$, yet be quite susceptible to soil-borne pathogens, whereas mycorrhizal species would be better defended against pathogens (Laliberté et al. 2015).

The interaction between pathogens and mycorrhizal fungi can promote plant diversity by several mechanisms (Laliberté et al. 2015; Marx 1972; Newsham et al. 1995a), such as negative density dependence, or by reducing the competitive strength of dominant plant species which allows subordinate species to coexist
(Terborgh 2012). For example, Albornoz et al. (2017) grew non-mycorrhizal Proteaceae and ECM Myrtaceae from P-impoverished south-western Australian shrublands, and found that ECM species are not affected by various native Phytophthora species isolated from these ecosystems, whereas non-mycorrhizal clusterrooted species are susceptible. When non-mycorrhizal and ECM plants are grown in competition with each other, inoculation with Phytophthora reduces the competitive superiority of non-mycorrhizal plants to the benefit of ECM species (Albornoz et al. 2017). Interestingly, there is a positive correlation between ECM root colonisation and ECM plant growth, but only in the presence of Phytophthora (Fig. 9), suggesting the ECM fungi play a stronger role in root defence against pathogens than in $\mathrm{P}$ acquisition in these severely $\mathrm{P}$ impoverished habitats (Albornoz et al. 2017). Further support for this concept is provided by Teste et al. (2017), who grew 16 plant species with different nutrient-acquisition strategies in a glasshouse. Plants were exposed to a sterilised soil inoculum, either collected from the rooting zones of conspecific mature plants, or from the rooting zones of species sharing the same or a different nutrient-acquisition strategy. Consistent with the hypothesis proposed by Laliberté et al. (2015), non-mycorrhizal plants showed reduced survival when exposed to a conspecific soil inoculum relative to a sterile inoculum, suggesting a role of pathogens. By contrast, the opposite was found for ECM species, which grew better when exposed to a conspecific inoculum relative to a sterile one (Teste et al. 2017). Other studies have also shown the defensive properties of mycorrhizal fungi against root pathogens (Branzanti and Zambonelli 1994; Branzanti et al. 1999; Marx 1972; Wehner et al. 2010). These studies, taken together with results from Albornoz et al. (2017), suggest that in old and severely-weathered soils, plant diversity may be enhanced by a trade-off between highly-efficient P-acquisition strategies and susceptibility to soil-borne pathogens (Laliberté et al. 2015). This mechanism could be an important factor in promoting plant coexistence in the south-western Australian biodiversity hotspot and possibly elsewhere where Proteaceae play a prominent role, e.g., fynbos in South Africa (Allsopp et al. 2014).

Albornoz et al. (2016b) concluded that a decline in ECM fungal richness and an increase in ECM root colonisation during ecosystem development along the Jurien Bay chronosequence was in favour of a small number of ECM fungal species that were the most 
Fig. 8 How belowground interactions with soil biota can lead to (a) negative density dependence or (b) mono dominance, depending on a plant nutrient-acquisition strategy. In (a), inoculum of soil-borne pathogens builds up in the root zone of mature non-mycorrhizal plants, leading to poor conspecific seedling survival and growth. Such negative density dependence promotes local plant species coexistence by preventing dominance by one species. In (b), seedlings of an ectomycorrhizal (ECM) plant species show greater survival and growth near a conspecific mature plant because they recruit into an established ECM fungal network that provides resistance against soilborne pathogens, while also enhancing $\mathrm{P}$ acquisition. Moreover, ECM fungi can directly suppress the activity of soil-borne pathogens. This can lead to monodominance by the ECM species. Figure taken from Laliberté et al. (2015) with permission from Wiley

\section{a Negative density dependence}

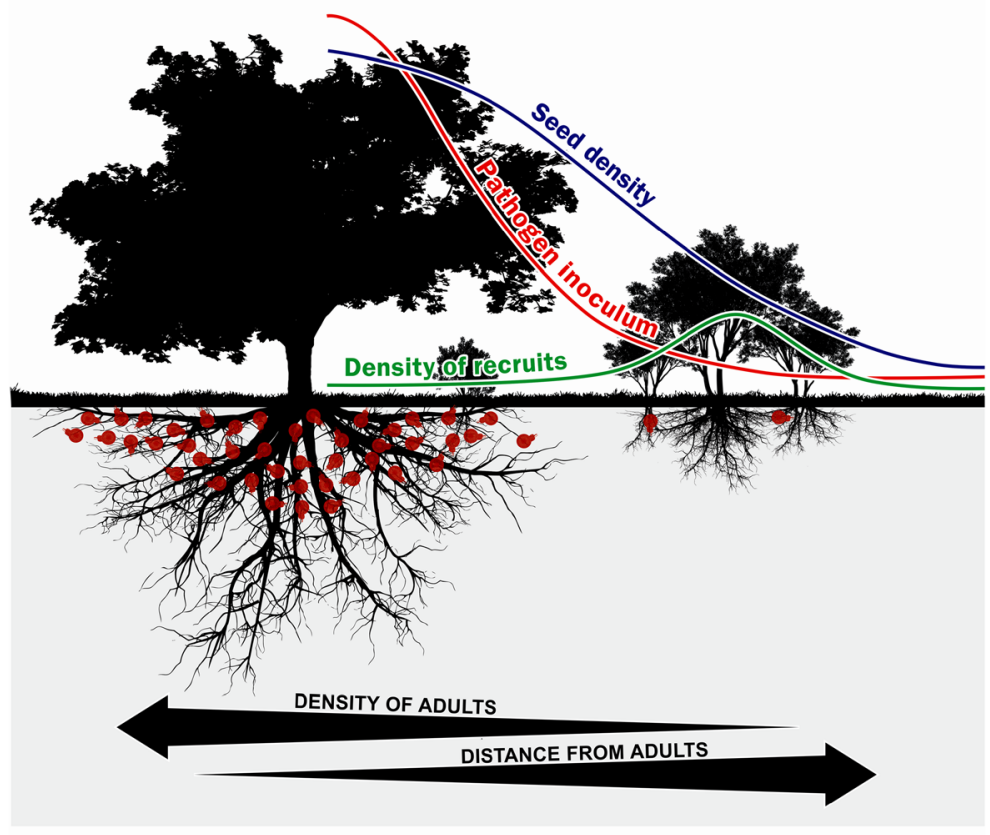

b Monodominance

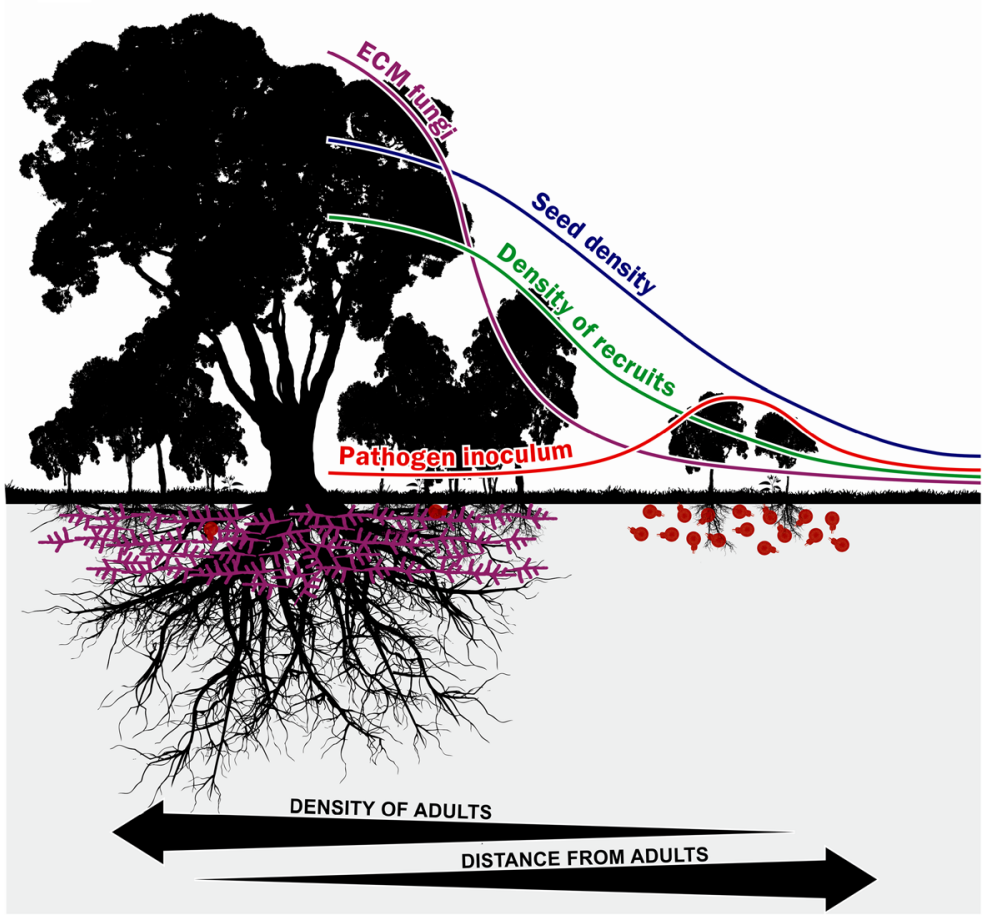

efficient at acquiring P. Based on further studies, Albornoz et al. (2017) inferred that in the same old soils, one of the ECM fungi's main roles could be defence against pathogens. Hence, mycorrhizal fungi may not only be driven by their nutrient-acquisition efficiency, but, in severely P-impoverished soils, more so by their ability to protect their hosts from pathogens. These results show a dual role of nutrient uptake and pathogen 
" ". (-) Phytophthora - (+) Phytophthora

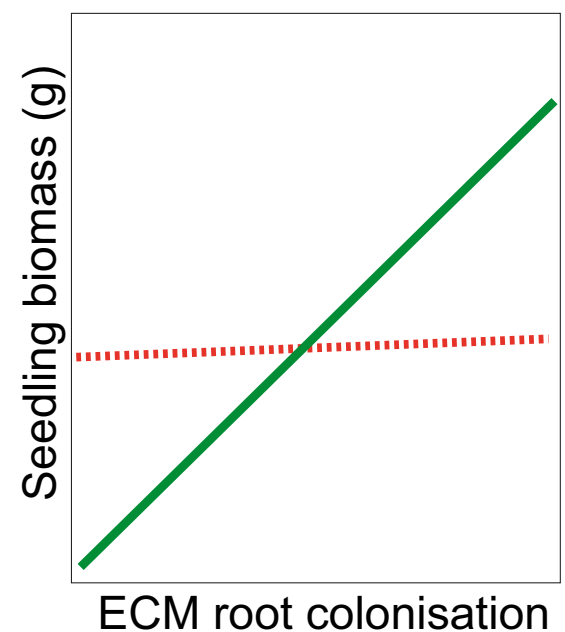

Fig. 9 Conceptual figure modified after Albornoz et al. (2017), which includes experimental data for three species. It shows the relationships between ectomycorrhizal root colonisation and seedling biomass in the presence or absence of Phytophthora species. The solid green line indicates the presence of Phytophthora and a significant relationship $(P \leq 0.05)$, while the red dashed line indicates the absence of Phytophthora and a non-significant relationship $(P \geq 0.05)$

defence of ECM fungi. Other studies have also shown the facilitative effects that plants can have on species with different nutrient-acquisition strategies (Li et al. 2014; Teste et al. 2014). We surmise that species that are less efficient at acquiring nutrients coexist with species with superior nutrient-acquisition strategies by possessing better defence against pathogens, possibly tapping into nutrients made available in the rhizosphere of their less well-defended competitors (Fig. 10).

In the preceding sections, we argued that clusterrooted species are particularly susceptible to pathogens. It has been shown, however, that cluster roots of Lupinus albus release a range of compounds that inhibit the activity of both bacteria and fungi (Tomasi et al. 2008; Weisskopf et al. 2006; Weisskopf et al. 2005). There is some evidence that cluster roots of Embothrium coccineum (Proteaceae) function in a similar manner (Delgado et al. 2015). Interestingly, the chitinases released by cluster roots of $L$. albus (Weisskopf et al. 2006) are ineffective against the cell walls of oomycetes (water moulds) such as Phytophthora and Pythium, because of their different cell-wall structure (Badreddine et al. 2008; Wessels 1994). Therefore, oomycetes, rather than fungi or bacteria, likely are the major pathogens affecting Proteaceae in hyperdiverse systems (Albornoz et al. 2017; Laliberté et al. 2015).
Concluding remarks on protection against pathogens

Two decades ago, a key question was about the paradoxical abundance of non-mycorrhizal species in severely $\mathrm{P}$-impoverished landscapes (Lambers et al. 2006). A series of studies showed that these nonmycorrhizal P-mining species have a superior Pacquisition strategy based on releasing large amounts of carboxylates (Lambers et al. 2008). Then, a new key question emerged: why are there so many P-scavenging mycorrhizal species in severely P-impoverished environments, when this strategy is presumably inferior for acquiring the growth-limiting resource (Lambers et al. 2014)? Now, we conclude that an important role of mycorrhizal fungi in severely $\mathrm{P}$-impoverished megadiverse landscapes is protection against pathogens, rather than nutrient uptake. Johnson et al. (1997) proposed that mycorrhizal associations fall into a mutualism-parasitism continuum based on several studies finding that mycorrhizal root colonisation can have positive to non-existent to negative effects on plant growth. We argue that this proposed continuum does not fully capture recent observations by focusing only on nutrient uptake and discarding other potential benefits that mycorrhizal fungi offer to their hosts, such as pathogen defence (Newsham et al. 1995b). Findings by Teste et al. (2016) showed overall low external mycorrhizal hyphal biomass in a severely P-impoverished habitat, indicating relatively little nutrient scavenging compared with that in other ecosystems, where the $\mathrm{P}$ availability is greater. Based on the evidence provided here, we propose that mycorrhizal fungi may not necessarily act as 'parasites' when they do not increase host nutrient uptake (Albornoz et al. 2017). Rather, their main effect on plants may change, depending on the environmental context (Sikes et al. 2010).

\section{Perspectives}

We focused on recent studies conducted along the Jurien Bay chronosequence located in a biodiversity hotspot (Laliberté et al. 2012), but placed these in as broad a context as possible. These studies have their limitations. Albornoz et al. (2017) only evaluated the role of pathogens in coexistence of plants with two nutrientacquisition strategies. There are more than 350 plant species along the Jurien Bay chronosequence with contrasting nutrient-acquisition strategies (Zemunik et al. 
Fig. 10 Diagram showing the net outcome of interaction between a mycorrhizal (plant on the left) and a non-mycorrhizal Proteaceae (plant on the right) in the absence (left panel) and presence (right panel) of native soil-borne pathogens. Drawing produced by Javier F. Tabima

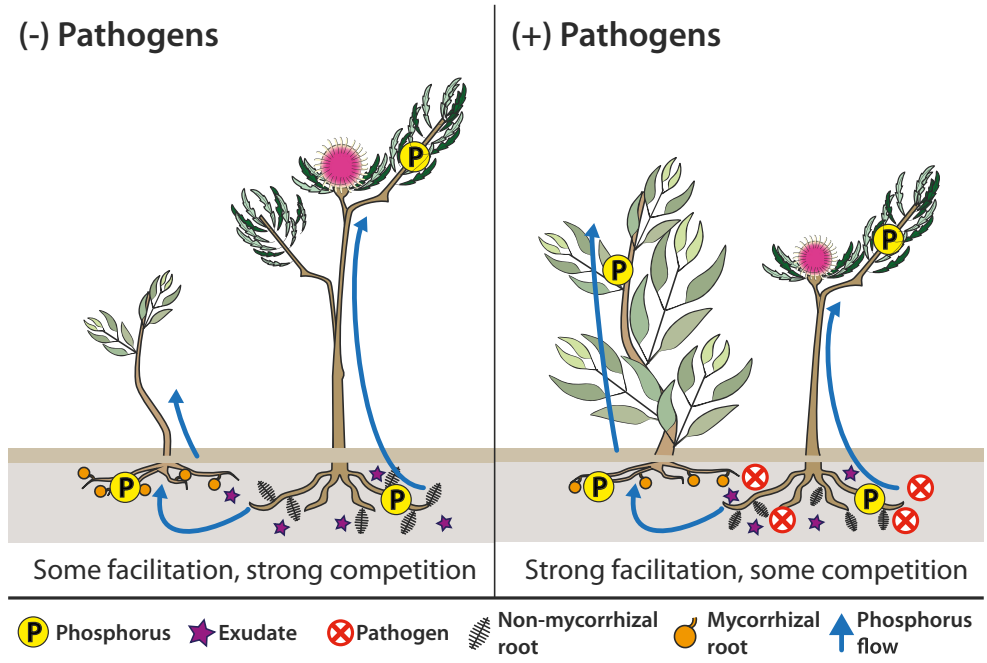

2015). Hence, results from Albornoz et al. (2017) do not necessarily explain the persistence of other nutrientacquisition strategies, such as species with dauciform roots (Cyperaceae) or sand-binding roots (Haemodoraceae). The situation for these may be very different, because Cyperaceae (Enstone et al. 2003; Perumalla et al. 1990) and Haemodoraceae (Layla Aerne-Hains and Simpson 2017) do have an exodermis. A trade-off between P-acquisition efficiency and pathogen defence in combination with facilitation of nutrient acquisition (Muler et al. 2014) may not be the only mechanism that maintains hyperdiverse ecosystems. This trade-off may explain why some species exhibit both a cluster-root strategy and mycorrhizas, e.g., Casuarinaceae, including Casuarina cunninghamiana (Reddell et al. 1997) and Allocasuarina humilis (Png et al. 2017), and some Fabaceae, e.g., Viminaria juncea (de Campos et al. 2013). It may not be a case of 'belt and braces', i.e. using two complementary strategies, but a matter of using cluster roots for effective nutrient acquisition and mycorrhizas for defence against pathogens.

Future studies should test the generality of the new hypotheses proposed in this review by using other nutrient-acquisition strategies and other nutrient-poor, highly diverse ecosystems, such as the fynbos in South Africa, tropical rainforests in South America and Asia (Myers et al. 2000), campos rupestres in Brazil (Oliveira et al. 2015; Silveira et al. 2016) or the pampas grasslands in southern South America (Hopper et al. 2016; Sainz Rozas et al. 2012). These future studies will not only enhance our understanding of the functioning of biodiversity hotspots, but also underpin management strategies to conserve or restore megadiverse ecosystems. Also, future research should aim to quantify the relative importance of different factors allowing plant coexistence, such as competitive and facilitative interactions through soil microbiota, and their implications for plant diversity. Furthermore, since cluster roots are ephemeral and likely fully deplete the scarce nutrients from their rhizosphere and proficiently remobilise the nutrients from their cluster roots (Shane et al. 2004), facilitation would be effective only if the roots of facilitated plants intermingled with cluster roots at the right time. This would require sensing where the cluster roots are going to be produced at a very early stage of cluster-root development. Such sensing would involve signalling molecules, likely volatiles that are released by roots or decaying microorganisms (Peñuelas et al. 2014; Waters et al. 2016; Weidenhamer 2016), which are affected by antimicrobial compounds released from developing cluster roots (Cesco et al. 2012; Delgado et al. 2015; Weisskopf et al. 2006).

Finally, disentangling the relative importance of the complementary roles of mycorrhizal fungi in nutrient uptake and pathogen defence is difficult, because these occur simultaneously. Future studies should aim at quantifying the relative contribution of the different benefits mycorrhizas can have for plant health by conducting multifactorial experiments using pathogen and mycorrhizal inoculum, and modifying soil nutrient availability (Maherali and Klironomos 2007; Sikes et al. 2009). 
Acknowledgements We acknowledge support from the Australian Research Council to H.L. (DP0985685, DP110101120, DP130100005, DP140100148, LP0776252, LP12020464, LP120200808) and E.L. (DE120100352, DP130100016, LP150100339) as well as from University of Western Australia Development Grants to H.L., F.P.T., and E.L. We appreciate the artistic input from Javier F. Tabima, who drew the diagram presented in Fig. 10, and thank Patrick Hayes and Sally Smith for feedback on an earlier version of this manuscript. We also acknowledge the use of the facilities at the Centre for Microscopy, Characterisation and Analysis located at UWA which are funded through university, state and commonwealth programmes.

\section{References}

Abbott LK, Robson AD, Boer GD (1984) The effect of phosphorus on the formation of hyphae in soil by the vesiculararbuscular mycorrhizal fungus, Glomus fasciculatum. New Phytol 97:437-446

Albornoz FE, Burgess TI, Lambers H, Etchells H, Laliberté E (2017) Native soil-borne pathogens equalise differences in competitive ability between plants of contrasting nutrientacquisition strategies. J Ecol 105:549-557

Albornoz FE, Lambers H, Turner BL, Teste FP, Laliberté E (2016a) Shifts in symbiotic associations in plants capable of forming multiple root symbioses across a long-term soil chronosequence. Ecol Evol 6:2368-2377

Albornoz FE, Teste FP, Lambers H, Bunce M, Murray DC, White NE, Laliberté E (2016b) Changes in ectomycorrhizal fungal community composition and declining diversity along a 2million-year soil chronosequence. Mol Ecol 25:4919-4929

Allsopp N, Colville JF, Verboom GA (2014) Fynbos: Ecology, Evolution, and Conservation of a Megadiverse Region. Oxford University Press, Oxford

Azcón-Aguilar C, Barea JM (1997) Arbuscular mycorrhizas and biological control of soil-borne plant pathogens - an overview of the mechanisms involved. Mycorrhiza 6:457-464

Badreddine I, Lafitte C, Heux L, Skandalis N, Spanou Z, Martinez Y, Esquerré-Tugayé M-T, Bulone V, Dumas B, Bottin A (2008) Cell wall chitosaccharides are essential components and exposed patterns of the phytopathogenic oomycete Aphanomyces euteiches. Eukaryot Cell 7:1980-1993

Bennett JA, Maherali H, Reinhart KO, Lekberg Y, Hart MM, Klironomos J (2017) Plant-soil feedbacks and mycorrhizal type influence temperate forest population dynamics. Science 355:181-184

Bever JD, Mangan SA, Alexander HM (2015) Maintenance of plant species diversity by pathogens. Annu Rev Ecol Evol Syst 46:305-325

Biggs AR, Miles NW (1988) Association of suberin formation in uninoculated wounds with susceptibility to Leucostoma cincta and $L$. persoonii in various peach cultivars. Phytopathology 78:1070-1074

Bonawitz ND, Chapple C (2010) The genetics of lignin biosynthesis: connecting genotype to phenotype. Annu Rev Genet 44:337-363
Bramley H, Turner NC, Turner DW, Tyerman SD (2009) Roles of morphology, anatomy, and aquaporins in determining contrasting hydraulic behavior of roots. Plant Physiol 150:348-364

Branzanti B, Zambonelli A (1994) In vitro effects of ectomycorrhizal fungi on Fusarium solani and Rhizoctonia solani damping off of pine seedlings. Petria (Italy) 4:131-140

Branzanti MB, Rocca E, Pisi A (1999) Effect of ectomycorrhizal fungi on chestnut ink disease. Mycorrhiza 9:103-109

Brooker RW, Maestre FT, Callaway RM, Lortie CL, Cavieres LA, Kunstler G, Liancourt P, Tielbörger K, Travis JMJ, Anthelme F, Armas C, Coll L, Corcket E, Delzon S, Forey E, Kikvidze Z, Olofsson J, Pugnaire F, Quiroz CL, Saccone P, Schiffers K, Seifan M, Touzard B, Michalet R (2008) Facilitation in plant communities: the past, the present, and the future. J Ecol 96 : $18-34$

Brundrett MC (2009) Mycorrhizal associations and other means of nutrition of vascular plants: understanding the global diversity of host plants by resolving conflicting information and developing reliable means of diagnosis. Plant Soil 320:37-77

Burrows N, Wardell-Johnson G (2003) Fire and plant interactions in forested ecosystems of south-west Western Australia. In: Abbott I, Burrows N (eds) Fire in Ecosystems of the Southwest Western Australia: Impact and Management. Backhuys Publishers, Leiden, pp 225-268

Cairney J (2011) Ectomycorrhizal fungi: the symbiotic route to the root for phosphorus in forest soils. Plant Soil 344:51-71

Callaway RM (1995) Positive interactions among plants. Bot Rev 61:306-349

Cameron DD, Neal AL, van Wees SCM, Ton J (2013) Mycorrhiza-induced resistance: more than the sum of its parts? Trends Plant Sci 18:539-545

Certini G (2005) Effects of fire on properties of forest soils: a review. Oecologia 143:1-10

Cesco S, Mimmo T, Tonon G, Tomasi N, Pinton R, Terzano R, Neumann G, Weisskopf L, Renella G, Landi L, Nannipieri P (2012) Plant-borne flavonoids released into the rhizosphere: impact on soil bio-activities related to plant nutrition. A review. Biol Fertil Soils 48:123-149

Clark LH, Harris WH (1981) Observations on the root anatomy of rice (Oryza sativa L.) Am J Bot 68:154-161

Coates DJ, Byrne M, Cochrane JA, Dunn C, Gibson N, Keighery GJ, Lambers H, Monks LT, Thiele KR, Yates CJ (2014) Conservation of the kwongan flora: threats and challenges. In: Lambers H (ed) Plant Life on the Sandplains in Southwest Australia, a Global Biodiversity Hotspot. UWA Publishing, Crawley, pp 263-284

Connell JH (1971) On the role of natural enemies in preventing competitive exclusion in some marine animals and in rain forest trees. In: Dynamics of Populations.. Eds. P den Boer, J, and G R Gradwell. Centre for Agricultural Publishing and Documentation, Wageningen, pp 298-313

Cowling RM, MacDonald IAW, Simmons MT (1996a) The Cape Peninsula, South Africa: physiographical, biological and historical background to an extraordinary hot-spot of biodiversity. Biodivers Conserv 5:527-550

Cowling RM, Potts AJ, Bradshaw PL, Colville J, Arianoutsou M, Ferrier S, Forest F, Fyllas NM, Hopper SD, Ojeda F, Procheș Ş, Smith RJ, Rundel PW, Vassilakis E, Zutta BR (2014) Variation in plant diversity in mediterranean-climate 
ecosystems: the role of climatic and topographical stability. $\mathrm{J}$ Biogeogr 42:552-564

Cowling RM, Richardson DM (1995) Fynbos: South Africa's Unique Floral Kingdom. Fernwood Press, Vlaeberg

Cowling RM, Rundel PW, Lamont BB, Kalin Arroyo M, Arianoutsou M (1996b) Plant diversity in mediterraneanclimate regions. Trends Ecol Evol 11:362-366

$\mathrm{Cu}$ STT, Hutson J, Schuller KA (2005) Mixed culture of wheat (Triticum aestivum L.) with white lupin (Lupinus albus L.) improves the growth and phosphorus nutrition of the wheat. Plant Soil 272:143-151

de Campos MCR, Pearse SJ, Oliveira RS, Lambers H (2013) Viminaria juncea does not vary its shoot phosphorus concentration and only marginally decreases its mycorrhizal colonization and cluster-root dry weight under a wide range of phosphorus supplies. Ann Bot 111:801-809

Delgado M, Zúñiga-Feest A, Almonacid L, Lambers H, Borie F (2015) Cluster roots of Embothrium coccineum (Proteaceae) affect enzyme activities and phosphorus lability in rhizosphere soil. Plant Soil 395:189-200

Delhaize E, Ryan PR, Randall PJ (1993) Aluminum tolerance in wheat (Triticum aestivum L.) (II. Aluminum-stimulated excretion of malic acid from root apices). Plant Physiol 103: 695-702

DeLuca TH, Zackrisson O, Gundale MJ, Nilsson M-C (2008) Ecosystem feedbacks and nitrogen fixation in boreal forests. Science 320:1181

Dickie IA, Guza RC, Krazewski SE, Reich PB (2004) Shared ectomycorrhizal fungi between a herbaceous perennial (Helianthemum bicknellii) and oak (Quercus) seedlings. New Phytol 164:375-382

Duchesne LC, Peterson RL, Ellis BE (1988a) Interaction between the ectomycorrhizal fungus Paxillus involutus and Pinus resinosa induces resistance to Fusarium oxysporum. Can J Bot 66:558-562

Duchesne LC, Peterson RL, Ellis BE (1988b) Pine root exudate stimulates the synthesis of antifungal compounds by the ectomycorrhizal fungus Paxillus involutus. New Phytol 108:471-476

Enkerli K, Mims CW, Hahn MG (1997) Ultrastructure of compatible and incompatible interactions of soybean roots infected with the plant pathogenic oomycete Phytophthora sojae. Can J Bot 75:1493-1508

Enstone DE, Peterson CA, Ma F (2003) Root endodermis and exodermis: structure, function, and responses to the environment. J Plant Growth Regul 21:335-351

Esau K (1977) Anatomy of seed plants. 2nd edition. John Wiley and Sons Inc., New York

Gardner WK, Barber DA, Parbery DG (1983) The acquisition of phosphorus by Lupinus albus L. III. The probable mechanism by which phosphorus movement in the soil/root interface is enhanced. Plant Soil 70:107-124

Gardner WK, Boundy KA (1983) The acquisition of phosphorus by Lupinus albus L. IV. The effect of interplanting wheat and white lupin on the growth and mineral composition of the two species. Plant Soil 70:391-402

Gibson N, Keighery GJ, Lyons MN, Webb A (2004) Terrestrial flora and vegetation of the Western Australian wheatbelt. Rec WA Mus 67:139-189
Gillett JB (1962) Pest pressure, an underestimated factor in evolution. Syst Assoc Publ 4:37-46

Halliday J, Pate JS (1976) Symbiotic nitrogen fixation by coralloid roots of the cycad Macrozamia riedlei: physiological characteristics and ecological significance. Funct Plant Biol 3:349358

Hansen AP, Pate JS (1987) Evaluation of the ${ }^{15} \mathrm{~N}$ natural abundance method and xylem sap analysis for assessing $\mathrm{N}_{2}$ fixation of understorey legumes in Jarrah (Eucalyptus marginata Donn ex Sm.) forest in S.W. Australia. J Exp Bot 38:14461458

Hart MM, Reader RJ, Klironomos JN (2003) Plant coexistence mediated by arbuscular mycorrhizal fungi. Trends Ecol Evol 18:418-423

Hartung W, Leport L, Ratcliffe RG, Sauter A, Duda R, Turner NC (2002) Abscisic acid concentration, root $\mathrm{pH}$ and anatomy do not explain growth differences of chickpea (Cicer arietinum L.) and lupin (Lupinus angustifolius L.) on acid and alkaline soils. Plant Soil 240:191-199

Hayes P, Turner BL, Lambers H, Laliberté E (2014) Foliar nutrient concentrations and resorption efficiency in plants of contrasting nutrient-acquisition strategies along a 2-million-year dune chronosequence. J Ecol 102:396-410

He X, Xu M, Qiu GY, Zhou J (2009) Use of ${ }^{15} \mathrm{~N}$ stable isotope to quantify nitrogen transfer between mycorrhizal plants. J Plant Ecol 2:107-118

Herre EA, Mejía LC, Kyllo DA, Rojas E, Maynard Z, Butler A, Van Bael SA (2007) Ecological implications of anti-pathogen effects of tropical fungal endophytes and mycorrhizae. Ecology 88:550-558

Hingston FJ, Malajczuk N, Grove TS (1982) Acetylene reduction $\left(\mathrm{N}_{2}\right.$-fixation) by jarrah forest legumes following fire and phosphate application. J Appl Ecol 19:631645

Hopmans P, Bauhus J, Khanna P, Weston C (2005) Carbon and nitrogen in forest soils: Potential indicators for sustainable management of eucalypt forests in south-eastern Australia. For Ecol Manag 220:75-87

Hopper SD (2009) OCBIL theory: towards an integrated understanding of the evolution, ecology and conservation of biodiversity on old, climatically buffered, infertile landscapes. Plant Soil 322:49-86

Hopper SD, Silveira FAO, Fiedler PL (2016) Biodiversity hotspots and Ocbil theory. Plant Soil 403:167-216

Horst WJ, Waschkies C (1987) Phosphatversorgung von Sommerweizen (Triticum aestivum L.) in Mischkultur mit weißer Lupine (Lupinus albus L.) Z Pflanzenernähr Bodenkd 150:1-8

Hose E, Clarkson DT, Steudle E, Schreiber L, Hartung W (2001) The exodermis: a variable apoplastic barrier. J Exp Bot 52: 2245-2264

Huang G, Hayes P E, Ryan M H, Pang J and Lambers H (2017) Peppermint trees shift their phosphorus-acquisition strategy along a strong gradient of plant-available phosphorus by increasing their transpiration. Oecologia in press

Huitema K, van den Dikkenberg J, Brouwers JF, Holthuis JC (2004) Identification of a family of animal sphingomyelin synthases. EMBO J 23:33-44 
Huston MA (1994) Biological Diversity. Cambridge University Press, Cambridge

Huston MA (2012) Precipitation, soils, NPP, and biodiversity: resurrection of Albrecht's curve. Ecol Monogr 82:277-296

Initiative I O C (2012) Western Australia's Weather and Climate: a Synthesis of Indian Ocean Climate Initiative Stage 3 Research. CSIRO and BoM, Australia

Jakobsen I and Hammer E (2015) Nutrient dynamics in arbuscular mycorrhizal networks. In Mycorrhizal Networks. Ed. T R Horton. pp 91-131. Springer Netherlands

Janzen DH (1970) Herbivores and the number of tree species in tropical forests. Am Nat 104:501-528

Johnson NC, Graham JH, Smith FA (1997) Functioning of mycorrhizal associations along the mutualism-parasitism continuum. New Phytol 135:575-585

Jones MD, Durall DM, Tinker PB (1992) Phosphorus relationships and production of extramatrical hyphae by two types of willow ectomycorrhizas at different soil phosphorus levels. New Phytol 115:259-267

Kennedy PG, Smith DP, Horton TR, Molina RJ (2012) Arbutus menziesii (Ericaceae) facilitates regeneration dynamics in mixed evergreen forests by promoting mycorrhizal fungal diversity and host connectivity. Am J Bot 99:1691-1701

Kolattukudy PE (1984) Biochemistry and function of cutin and suberin. Can J Bot 62:2918-2933

Kolattukudy PE, Espelie KE (1989) Chemistry, biochemistry and functions of suberin associated waxes. In: Natural Products of Woody Plants I. Ed. J W Rowe. Springer-Verlag, New York, pp 235-287

Krüger M, Teste FP, Laliberté E, Lambers H, Coghlan M, Zemunik G, Bunce M (2015) The rise and fall of arbuscular mycorrhizal fungal diversity during ecosystem retrogression. Mol Ecol 24:4912-4930

Laliberté E, Grace JB, Huston MA, Lambers H, Teste FP, Turner BL, Wardle DA (2013) How does pedogenesis drive plant diversity? Trends Ecol Evol 28:331-340

Laliberté E, Kardol P, Didham R K, Teste F P, Turner B L and Wardle D A (2017) Soil fertility shapes belowground food webs across a regional climate gradient. Ecol Lett, n/a-n/a

Laliberté E, Lambers H, Burgess TI, Wright SJ (2015) Phosphorus limitation, soil-borne pathogens and the coexistence of plant species in hyperdiverse forests and shrublands. New Phytol 206:507-521

Laliberté E, Turner BL, Costes T, Pearse SJ, Wyrwolll K-H, Zemunik G, Lambers H (2012) Experimental assessment of nutrient limitation along a 2 -million year dune chronosequence in the south-western Australia biodiversity hotspot. J Ecol 100:631-642

Lambers H, Brundrett MC, Raven JA, Hopper SD (2010) Plant mineral nutrition in ancient landscapes: high plant species diversity on infertile soils is linked to functional diversity for nutritional strategies. Plant Soil 334:11-31

Lambers H, Clements JC, Nelson MN (2013) How a phosphorusacquisition strategy based on carboxylate exudation powers the success and agronomic potential of lupines (Lupinus, Fabaceae). Am J Bot 100:263-288

Lambers H, Clode PL, Hawkins H-J, Laliberté E, Oliveira RS, Reddell P, Shane MW, Stitt M, Weston P (2015a) Metabolic adaptations of the non-mycotrophic Proteaceae to soil with a low phosphorus availability. In: Plaxton WC, Lambers $\mathrm{H}$ (eds) Annual Plant Reviews, Volume 48, Phosphorus
Metabolism in Plants. John Wiley \& Sons, Chicester, pp 289-336

Lambers H, Finnegan P M, Jost R, Plaxton W C, Shane M W and Stitt M (2015b) Phosphorus nutrition in Proteaceae and beyond. Nat Plants 1

Lambers H, Hayes PE, Laliberté E, Oliveira RS, Turner BL (2015c) Leaf manganese accumulation and phosphorusacquisition efficiency. Trends Plant Sci 20:83-90

Lambers H, Martinoia E, Renton M (2015d) Plant adaptations to severely phosphorus-impoverished soils. Curr Opin Plant Biol 25:23-31

Lambers H, Raven JA, Shaver GR, Smith SE (2008) Plant nutrient-acquisition strategies change with soil age. Trends Ecol Evol 23:95-103

Lambers H, Shane MW, Cramer MD, Pearse SJ, Veneklaas EJ (2006) Root structure and functioning for efficient acquisition of phosphorus: matching morphological and physiological traits. Ann Bot 98:693-713

Lambers H, Shane MW, Laliberté E, Swarts ND, Teste FP, Zemunik G (2014) Plant mineral nutrition. In: Lambers H (ed) Plant Life on the Sandplains in Southwest Australia, a Global Biodiversity Hotspot. UWA Publishing, Crawley, pp 101-127

Lamont B (1982) Mechanisms for enhancing nutrient uptake in plants, with particular reference to Mediterranean South Africa and Western Australia. Bot Rev 48:597-689

Lamont BB, Downes S, Fox JED (1977) Importance-value curves and diversity indices applied to a species-rich heathland in Western Australia. Nature 265:438-441

Layla Aerne-Hains L, Simpson MG (2017) Vegetative anatomy of the Haemodoraceae and its phylogenetic significance. Int J Plant Sci 178:117-156

Li H, Zhang F, Rengel Z, Shen J (2013) Rhizosphere properties in monocropping and intercropping systems between faba bean (Vicia faba L.) and maize (Zea mays L.) grown in a calcareous soil. Crop Pasture Sci 64:976-984

Li L, Li S-M, Sun J-H, Zhou L-L, Bao X-G, Zhang H-G, Zhang FS (2007) Diversity enhances agricultural productivity via rhizosphere phosphorus facilitation on phosphorus-deficient soils. Proc Natl Acad Sci U S A 104:11192-11196

Li L, Tilman D, Lambers H, Zhang F (2014) Plant diversity and overyielding: insights from belowground facilitation of intercropping in agriculture. New Phytol 203:63-69

Li X-L, George E, Marschner H (1991a) Extension of the phosphorus depletion zone in VA-mycorrhizal white clover in a calcareous soil. Plant Soil 136:41-48

Li X-L, George E, Marschner H (1991b) Phosphorus depletion and $\mathrm{pH}$ decrease at the root-soil and hyphae-soil interfaces of VA mycorrhizal white clover fertilized with ammonium. New Phytol 119:397-404

Liang M, Liu X, Etienne RS, Huang F, Wang Y, Yu S (2015) Arbuscular mycorrhizal fungi counteract the Janzen-Connell effect of soil pathogens. Ecology 96:562-574

Lulai EC, Corsini DL (1998) Differential deposition of suberin phenolic and aliphatic domains and their roles in resistance to infection during potato tuber (Solanum tuberosumL.) woundhealing. Physiol Mol Plant Pathol 53:209-222

Lygin AV, Li S, Vittal R, Widholm JM, Hartman GL, Lozovaya VV (2009) The importance of phenolic metabolism to limit the growth of Phakopsora pachyrhizi. Phytopathology 99: $1412-1420$ 
Ma JF, Ueno H, Ueno D, Rombolà AD, Iwashita T (2003) Characterization of phytosiderophore secretion under Fe deficiency stress in Festuca rubra. Plant Soil 256:131-137

Maherali H, Klironomos JN (2007) Influence of phylogeny on fungal community assembly and ecosystem functioning. Science 316:1746-1748

Marschner H (1995) Mineral Nutrition of Higher Plants. Academic Press, London

Marx DH (1969) The influence of ectotrophic mycorrhizal fungi on the resistance of pine roots to pathogenic infections. I. Antagonism of mycorrhizal fungi to root pathogenic fungi and soil bacteria. Phytopathology 59:153-163

Marx DH (1972) Ectomycorrhizae as biological deterrents to pathogenic root infections. Annu Rev Phytopathol 10:429454

McArthur WM (1991) Reference soils of south-western Australia. Department of Agriculture Western Australia, South Perth

McIntire EJB, Fajardo A (2014) Facilitation as a ubiquitous driver of biodiversity. New Phytol 201:403-416

McKane RB, Johnson LC, Shaver GR, Nadelhoffer KJ, Rastetter EB, Fry B, Giblin AE, Kielland K, Kwiatkowski BL, Laundre JA, Murray G (2002) Resource-based niches provide a basis for plant species diversity and dominance in arctic tundra. Nature 415:68-71

McMullan-Fisher SJM, May TW, Robinson RM, Bell TL, Lebel T, Catcheside P, York A (2011) Fungi and fire in Australian ecosystems: a review of current knowledge, management implications and future directions. Aust J Bot 59:70-90

Minton MM, Barber NA, Gordon LL (2016) Effects of arbuscular mycorrhizal fungi on herbivory defense in two Solanum (Solanaceae) species. Plant Ecol Evol 149:157-164

Moura JCMS, Bonine CAV, De Oliveira Fernandes Viana J, Dornelas MC, Mazzafera P (2010) Abiotic and biotic stresses and changes in the lignin content and composition in plants. $\mathrm{J}$ Integr Plant Biol 52:360-376

Muler AL, Oliveira RS, Lambers H, Veneklaas EJ (2014) Does cluster-root activity of Banksia attenuata (Proteaceae) benefit phosphorus or micronutrient uptake and growth of neighbouring shrubs? Oecologia 174:23-31

Myers N, Mittermeier RA, Mittermeier CG, da Fonseca GAB, Kent J (2000) Biodiversity hotspots for conservation priorities. Nature 403:853-858

Nagarajah S, Posner AM, Quirk JP (1970) Competitive adsorption of phosphate with polygalacturonate and other organic anions on kaolinite and oxide surfaces. Nature 228:83-85

Newsham KK, Fitter AH, Watkinson AR (1995a) Arbuscular mycorrhiza protect an annual grass from root pathogenic fungi in the field. J Ecol 85:991-1000

Newsham KK, Fitter AH, Watkinson AR (1995b) Multifunctionality and biodiversity in arbuscular mycorrhizas. Trends Ecol Evol 10:407-411

Oburger E, Gruber B, Schindlegger Y, Schenkeveld WDC, Hann S, Kraemer SM, Wenzel WW, Puschenreiter M (2014) Root exudation of phytosiderophores from soil-grown wheat. New Phytol 203:1161-1174

Oliveira RS, Galvão HC, de Campos MCR, Eller CB, Pearse SJ, Lambers H (2015) Mineral nutrition of campos rupestres plant species on contrasting nutrient-impoverished soil types. New Phytol 205:1183-1194

Orians GH, Milewski AV (2007) Ecology of Australia: The effects of nutrient-poor soils and intense fires. Biol Rev 82:393-423
Owusu-Bennoah E, Wild A (1979) Autoradiography of the depletion zone of phosphate around onion roots in the presence of vesicular-arbuscular mycorrhiza. New Phytol 82:133-140

Pate JS, Beard JS (eds) (1984) Kwongan. Plant Life of the Sandplain. University of Western Australia Press, Nedlands

Paul EA (2014) Soil Microbiology, Ecology and Biochemistry. Elsevier Academic Press, Amsterdam

Pearse SJ, Veneklaas EJ, Cawthray GR, Bolland MDA, Lambers H (2006) Carboxylate release of wheat, canola and 11 grain legume species as affected by phosphorus status. Plant Soil 288:127-139

Peay KG (2016) The mutualistic niche: mycorrhizal symbiosis and community dynamics. Annu Rev Ecol Evol Syst 47:143-164

Pekin BK, Wittkuhn RS, Boer MM, Macfarlane C, Grierson PF (2011) Plant functional traits along environmental gradients in seasonally dry and fire-prone ecosystem. J Veg Sci 22: $1009-1020$

Peñuelas J, Asensio D, Tholl D, Wenke K, Rosenkranz M, Piechulla B, Schnitzler JP (2014) Biogenic volatile emissions from the soil. Plant Cell Environ 37:1866-1891

Perumalla CJ, Peterson CA (1986) Deposition of Casparian bands and suberin lamellae in the exodermis and endodermis of young corn and onion roots. Can $\mathrm{J}$ Bot 64:1873-1878

Perumalla CJ, Peterson CA, Enstone DE (1990) A survey of angiosperm species to detect hypodermal Casparian bands. I. Roots with a uniseriate hypodermis and epidermis. Bot $\mathrm{J}$ Linn Soc 103:93-112

Png G K, Turner B L, Albornoz F E, Hayes P E, Lambers H and Laliberté E (2017) Greater root phosphatase activity in nitrogen-fixing rhizobial but not actinorhizal plants with declining phosphorus availability. J Ecol, n/a-n/a

Power SC, Cramer MD, Verboom GA, Chimphango SBM (2010) Does phosphate acquisition constrain legume persistence in the fynbos of the Cape Floristic Region? Plant Soil 334:3346

Pozo MJ, Cordier C, Dumas-Gaudot E, Gianinazzi S, Barea JM, Azcón-Aguilar C (2002) Localized versus systemic effect of arbuscular mycorrhizal fungi on defence responses to Phytophthora infection in tomato plants. J Exp Bot 53:525534

Ranathunge K, Thomas RH, Fang X, Peterson CA, Gijzen M, Bernards MA (2008) Soybean root suberin and partial resistance to root rot caused by Phytophthora sojae. Phytopathology 98:1179-1189

Raven JA (2012) Protein turnover and plant RNA and phosphorus requirements in relation to nitrogen fixation. Plant Sci 188189:25-35

Reddell P, Yun Y, Shipton WA (1997) Cluster roots and mycorrhizae in Casuarina cunninghamiana: their occurrence and formation in relation to phosphorus supply. Aust J Bot 45: $41-51$

Richardson S, Peltzer D, Allen R, McGlone M, Parfitt R (2004) Rapid development of phosphorus limitation in temperate rainforest along the Franz Josef soil chronosequence. Oecologia 139:267-276

Richter G (1996) Biochemie der Pflanze. Georg Thieme Verlag, Stuttgart

Sainz Rozas H, Echeverria H, Angelini H (2012) Available phosphorus in agricultural soils of the Pampa and Argentina 
ExtraPampeana. RIA, Revista de Investigaciones Agropecuarias 38:33-39

Schappe T, Albornoz F E, Turner B L, Neat A, Condit R and Jones F A (2017) The role of soil chemistry and plant neighbourhoods in structuring fungal communities in three Panamanian rainforests. J Ecol

Schmidt S, Stewart GR (1997) Waterlogging and fire impacts on nitrogen availability and utilization in a subtropical wet heathland (wallum). Plant Cell Environ 20:1231-1241

Schreiber L, Hartmann K, Skrabs M, Zeier J (1999) Apoplastic barriers in roots: chemical composition of endodermal and hypodermal cell walls. J Exp Bot 50:1267-1280

Shane MW, Cramer MD, Funayama-Noguchi S, Cawthray GR, Millar AH, Day DA, Lambers H (2004) Developmental physiology of cluster-root carboxylate synthesis and exudation in harsh hakea. Expression of phosphoenolpyruvate carboxylase and the alternative oxidase. Plant Physiol 135: 549-560

Shane MW, Lambers H (2005) Cluster roots: a curiosity in context. Plant Soil 274:101-125

Shearer BL, Crane CE, Cochrane A (2004) Quantification of the susceptibility of the native flora of the South-West Botanical Province, Western Australia, to Phytophthora cinnamomi. Aust J Bot 52:435-443

Sikes BA, Cottenie K, Klironomos JN (2009) Plant and fungal identity determines pathogen protection of plant roots by arbuscular mycorrhizas. J Ecol 97:1274-1280

Sikes BA, Powell JR, Rillig MC (2010) Deciphering the relative contributions of multiple functions within plant-microbe symbioses. Ecology 91:1591-1597

Silveira FO, Negreiros D, Barbosa NU, Buisson E, Carmo F, Carstensen D, Conceição A, Cornelissen T, Echternacht L, Fernandes GW, Garcia Q, Guerra T, Jacobi C, Lemos-Filho J, Le Stradic S, Morellato L, Neves F, Oliveira R, Schaefer C, Viana P, Lambers H (2016) Ecology and evolution of plant diversity in the endangered campo rupestre: a neglected conservation priority. Plant Soil 403:129-152

Simard S, Asay A, Beiler K, Bingham M, Deslippe J, He X, Philip L, Song Y and Teste F (2015) Resource transfer between plants through ectomycorrhizal fungal networks. In Mycorrhizal Networks. Ed. T R Horton. pp 133-176. Springer Netherlands

Simard SW, Beiler KJ, Bingham MA, Deslippe JR, Philip LJ, Teste FP (2012) Mycorrhizal networks: mechanisms, ecology and modelling. Fungal Biol Rev 26:39-60

Smith S E, Anderson I C and Smith F A (2015) Mycorrhizal associations and $\mathrm{P}$ acquisition: from cells to ecosystems In Annual Plant Reviews, Volume 48, Phosphorus Metabolism in Plants. Eds. W C Plaxton and H Lambers pp 409-440. John Wiley \& Sons

Smith SE, Read DJ (2008) Mycorrhizal Symbiosis. Academic Press and Elsevier, London

Stachowicz JJ (2001) Mutualism, facilitation, and the structure of ecological communities. Bioscience 51:235-246

Steudle E, Peterson CA (1998) Review article. How does water get through roots? J Exp Bot 49:775-788

Strobel N, Sinclair W (1991) Role of flavanolic wall infusions in the resistance induced by Laccaria bicolor to Fusarium oxysporum in primary roots of Douglas-fir. Pathology 81: $420-425$
Sun L, Lu Y, Yu F, Kronzucker HJ, Shi W (2016) Biological nitrification inhibition by rice root exudates and its relationship with nitrogen-use efficiency. New Phytol 212:646-656

Terborgh J (2012) Enemies maintain hyperdiverse tropical forests. Am Nat 179:303-314

Teste FP, Kardol P, Turner BL, Wardle DA, Zemunik G, Renton M, Laliberté E (2017) Plant-soil feedback and the maintenance of diversity in Mediterranean-climate shrublands. Science 355:173-176

Teste FP, Laliberté E, Lambers H, Auer Y, Kramer S, Kandeler E (2016) Mycorrhizal fungal biomass and scavenging declines in phosphorus-impoverished soils during ecosystem retrogression. Soil Biol Biochem 92:119-132

Teste FP, Simard SW, Durall DM, Guy RD, Jones MD, Schoonmaker AL (2009) Access to mycorrhizal networks and roots of trees: importance for seedling survival and resource transfer. Ecology 90:2808-2822

Teste FP, Veneklaas EJ, Dixon KW, Lambers H (2014) Complementary plant nutrient-acquisition strategies facilitate growth of neighbouring species. Funct Ecol 28:819-828

Teste FP, Veneklaas EJ, Dixon KW, Lambers H (2015) Is nitrogen transfer among plants enhanced by contrasting nutrientacquisition strategies? Plant Cell Environ 38:50-60

Thomas R, Fang X, Ranathunge K, Anderson TR, Peterson CA, Bernards MA (2007) Soybean root suberin: anatomical distribution, chemical composition, and relationship to partial resistance to Phytophthora sojae. Plant Physiol 144:299-311

Tomasi N, Weisskopf L, Renella G, Landi L, Pinton R, Varanini Z, Nannipieri P, Torrent J, Martinoia E, Cesco S (2008) Flavonoids of white lupin roots participate in phosphorus mobilization from soil. Soil Biol Biochem 40:1971-1974

Turner BL (2008) Resource partitioning for soil phosphorus: a hypothesis. J Ecol 96:698-702

Turner BL, Condron LM (2013) Pedogenesis, nutrient dynamics, and ecosystem development: the legacy of T.W. Walker and J.K. Syers. Plant Soil 367:1-10

Turner BL, Laliberté E (2015) Soil development and nutrient availability along a 2 million-year coastal dune chronosequence under species-rich Mediterranean shrubland in southwestern Australia. Ecosystems 18:287-309

Turner B L, Laliberté E and Hayes P E (2017) A climosequence of chronosequences in southwestern Australia. bioRxiv

Valentine AJ, Kleinert A, Benedito VA (2017) Adaptive strategies for nitrogen metabolism in phosphate deficient legume nodules. Plant Sci 256:46-52

Veneklaas EJ, Stevens J, Cawthray GR, Turner S, Grigg AM, Lambers H (2003) Chickpea and white lupin rhizosphere carboxylates vary with soil properties and enhance phosphorus uptake. Plant Soil 248:187-197

Vitousek PM, Cassman K, Cleveland C, Crews T, Field CB, Grimm NB, Howarth RW, Marino R, Martinelli L, Rastetter EB, Sprent JI (2002) Towards an ecological understanding of biological nitrogen fixation. Biogeochemistry 57-58:1-45

Vitousek P M, Menge D N L, Reed S C and Cleveland C C (2013) Biological nitrogen fixation: rates, patterns and ecological controls in terrestrial ecosystems. Phil Trans R Soc B: Biol Sci 368

Vos C, Schouteden N, van Tuinen D, Chatagnier O, Elsen A, De Waele D, Panis B, Gianinazzi-Pearson V (2013) Mycorrhizainduced resistance against the root-knot nematode 
Meloidogyne incognita involves priming of defense gene responses in tomato. Soil Biol Biochem 60:45-54

Walker TW, Syers JK (1976) The fate of phosphorus during pedogenesis. Geoderma 15:1-9

Wall LG (2000) The actinorhizal symbiosis. J Plant Growth Regul 19:167-182

Wardle DA, Bardgett RD, Walker LR, Peltzer DA, Lagerström A (2008) The response of plant diversity to ecosystem retrogression: evidence from contrasting long-term chronosequences. Oikos 117:93-103

Waters EM, Soini HA, Novotny MV, Watson MA (2016) Volatile organic compounds (VOCs) drive nutrient foraging in the clonal woodland strawberry, Fragaria vesca. Plant Soil 407(1-2):261-274

Watt M, Evans JR (1999) Linking development and determinacy with organic acid efflux from proteoid roots of white lupin grown with low phosphorus and ambient or elevated atmospheric $\mathrm{CO}_{2}$ concentration. Plant Physiol 120:705-716

Wehner J, Antunes PM, Powell JR, Mazukatow J, Rillig MC (2010) Plant pathogen protection by arbuscular mycorrhizas: a role for fungal diversity? Pedobiologia 53:197-201

Weidenhamer JD (2016) Plant olfaction: using analytical chemistry to elucidate mechanisms of plant growth and interaction. Plant Soil 407:275-278

Weisskopf L, Abou-Mansour E, Fromin N, Tomasi N, Santelia D, Edelkott I, Neumann G, Aragno M, Tabacchi R, Martinoia E (2006) White lupin has developed a complex strategy to limit microbial degradation of secreted citrate required for phosphate acquisition. Plant Cell Environ 29:919-927
Weisskopf L, Fromin N, Tomasi N, Aragno M, Martinoia E (2005) Secretion activity of white lupin's cluster roots influences bacterial abundance, function and community structure. Plant Soil 268:181-194

Wessels JGH (1994) Developmental regulation of fungal cell wall formation. Annu Rev Phytopathol 32:413-437

Williams RJ, Bradstock RA (2008) Large fires and their ecological consequences: introduction to the special issue. Int J Wildland Fire 17:685-687

Witkowski ETF, Mitchell DT (1987) Variations in soil phosphorus in the fynbos biome, South Africa. J Ecol 75:1159-1171

Wittkuhn RS, Lamont BB, He T (2017) Combustion temperatures and nutrient transfers when grasstrees burn. For Ecol Manag 399:179-187

Wright A J, Wardle D A, Callaway R and Gaxiola A (2017) The overlooked role of facilitation in biodiversity experiments. Trends Ecol Evol

Yao Q, Li X, Feng G, Christie P (2001) Mobilization of sparingly soluble inorganic phosphates by the external mycelium of an abuscular mycorrhizal fungus. Plant Soil 230:279-285

Zemunik G, Turner BL, Lambers H, Laliberté E (2015) Diversity of plant nutrient-acquisition strategies increases during longterm ecosystem development. Nat Plants 1. https://doi. org/10.1038/nplants.2015.1050

Zemunik G, Turner BL, Lambers H, Laliberté E (2016) Increasing plant species diversity and extreme species turnover accompany declining soil fertility along a long-term chronosequence in a biodiversity hotspot. J Ecol 104:792-805 